\title{
Kimberley marine biota. Historical data: polychaetes (Annelida)
}

\author{
Pat Hutchings ${ }^{1 *}$, Chris Glasby ${ }^{2}$, Maria Capa ${ }^{1,4}$ and Alison Sampey ${ }^{3}$ \\ ${ }^{1}$ Australian Museum, 6 College Street, Sydney NSW 2010. \\ ${ }^{2}$ Museum and Art Gallery of the Northern Territory, GPO Box 4646, Darwin NT 0801 \\ ${ }^{3}$ Department of Aquatic Zoology, Western Australian Museum, Locked Bag 49, \\ Welshpool DC WA 6986 \\ ${ }^{4}$ Museum of Natural History and Archaeology, Norwegian University of Science and Technology, \\ NO-7491 Trondheim, Norway \\ *Email: pat.hutchings@austmus.gov.au
}

\begin{abstract}
We examined all the previously published records of polychaetes from the Kimberley Project Area as well as unpublished records from Australian museum records and updated any recent nomenclatural changes. Over 260 species from 43 families have been reported and we suggest that this number will increase considerably as more survey work is carried out in the area and additional habitats such as soft sediments are properly surveyed. At this stage many of these species appear to have wide distributions with few endemic species recorded, but we anticipate this will increase with taxonomic revisions incorporating both molecular and morphological techniques. We hope this paper will advertise the availability of this material to specialists for incorporation into their Australian revisions.
\end{abstract}

KEYWORDS: natural history collections, species inventory, Kimberley region, biodiversity, north west Australia, baseline

\section{INTRODUCTION}

The importance of utilising natural history collection datasets to provide baseline biodiversity information for conservation and environmental management decisions is now recognised (Pyke and Ehrlich 2010). The Kimberley region of Australia is currently of great interest for its conservation value, with a number of proposed marine protected areas, and also for its oil and gas reserves, fishing and aquaculture activities, nature based tourism, and proposed development (Department of Environment and Conservation 2009). Consequently, baseline data to characterise the values and assets in the region are needed (Wood and Mills 2008).

The Western Australian Museum (WAM) and other Australian natural history institutions have undertaken marine biodiversity surveys of the species present in the Kimberley, but many of these data and their interpretations are either unpublished or published in specialist taxonomic literature, so not readily accessible to researchers and managers. To address this, WAM instigated an extensive data compilation of major taxa known from the Kimberley region. Wilson (2014) has reviewed the habitat and historical background of the Kimberley Project Area. Here, we document what is currently known about shallow water polychaete diversity within the Kimberley Project Area.

\section{POLYCHAETES (ANNELIDA)}

Polychaetes are a major component of the marine benthos in terms of number of both individuals and species. They range in length from less than 1 $\mathrm{mm}$ to over $1 \mathrm{~m}$. Polychaetes are currently classified into more than 80 families with over 15,000 species known worldwide and many remaining to be described. They vary considerably in morphology and life style, including many different types of feeding strategies (carnivores, deposit and filter feeders, herbivores, parasitic or commensal). They exhibit a considerable range of reproductive strategies including both sexual and asexual. Some species live only a few weeks, while others live for several years. They may breed almost continuously, or have a restricted breeding season. Some survive spawning and others do not. They live in a wide variety of marine habitats from the supra-littoral to the deep sea: some live in sediments, others bore 
into hard substrates or are firmly attached to them, while others move freely over the substrate, swim in the water column or are commensal on a range of animals. Some are tubiculous, living in muddy/ sandy or calcareous tubes. For all these reasons polychaetes have been widely used as surrogates for the entire benthic community. Because they occupy all levels within the food chain a diverse polychaete assemblage provides a good indication of a healthy environment. In addition, some taxa (e.g. some species of Capitellidae, such as Capitella spp.) are good indicators of polluted environments. As well as marine species, others occur in estuarine areas and freshwater habitats, and some terrestrial species live in damp environments (Beesley et al. 2000; Rouse and Pleijel 2001).

\section{HISTORY}

Historical collections of polychaetes from the Kimberley coast are scarce. In the late 1800s and early 1900s two expeditions collected in Western Australia: the German S.M.S. Gazelle between 1874 and 1876 and the south west Australian Hamburg expedition led by Michaelsen and Hartmeyer in 1905. The former did not extend north of the Dampier Archipelago and the latter only reached north to Shark Bay. Apparently, the only European expedition that sampled the Kimberley coast was the Swedish Mjöberg Scientific Expedition (1910-1911), for which the polychaetes were reported by Johansson (1918) and Augener (1922). All the polychaetes described by Augener came from a small area off Cape Jaubert in the southern Kimberley. No further notable collecting of polychaetes occurred until 1975 when HartmannSchröder and Hartmann collected at several sites around Broome and Derby as part of their Australiawide investigation of intertidal polychaetes and ostracods. All the specimens studied by Augener (1922) and Hartmann-Schröder (1979) - over 260 specimen lots - were deposited in the Zoologisches Institut und Zoologisches Museum der Universität
Hamburg, Germany (HZM), except for some paratypes, which are housed at WAM.

The first extensive survey of polychaetes along the Kimberley coast was made in 1988 (Hutchings 1989). Polychaetes were collected from 29 locations with 121 species identified (Table 1). Many of the species collected during this survey were new and have been described subsequently (Hutchings and Glasby 1990; Hutchings and Reid 1990, 1991; Pillai 2009; Murray et al. 2010). Polychaetes were also collected during a 1991 survey of 21 locations along the coast between Broome and Wyndham (referred to as the KIRE 91), by WAM where 54 taxa were identified, to either species or family level by Hanley (1992). Hanley recorded the greatest diversity within the Polynoidae with 20 species identified, including three new species. Other common families were the Nereididae and Terebellidae. Hanley was particularly interested in polynoids commensal with holothurians, crinoids, alcyonarians and gorgonians and with one species commensal in tubes of terebellids. In a second survey to the southern Kimberley in 1994, polychaetes associated with intertidal hard substrates and mangroves were collected. Specimens from both surveys are lodged at the Museum and Art Gallery of the Northern Territory (MAGNT). Hanley (1995) provides a list of the polychaete families collected with the polynoids and the eunicids identified to species. Both of these reports suggest a high diversity of polychaetes with new species as well as widely distributed ones commonly found in similar habitats throughout northern Australia, although many of these widely distributed species need to be carefully re-examined to confirm their identifications.

Additional surveys were carried out by MAGNT and also by WAM in the 1980s and in 2008, but polychaetes were not specifically targeted and no species lists were compiled. These included an initial 1984 survey of Ashmore, Cartier and Hibernia Reefs by MAGNT (Russell 2005), followed by those in 1987 and 1992, yielding many polychaete specimens now housed at MAGNT.

TABLE $1 \quad$ Number of locations, species and families of the polychaetes sampled during main survey expeditions in the region and presented as reports. ${ }^{*}$ Number of species not presented in the report so the number was extracted from the database.

\begin{tabular}{lllll} 
Survey year & No. locations & No. species & No. families & Reference \\
\hline 1988 & 29 & 121 & 13 & Hutchings 1989* \\
1991 & 21 & $54+$ & 21 & Hanley 1992 \\
1994 & 10 & $50+$ & 22 & Hanley 1995 \\
\hline
\end{tabular}


All the records discussed above are incorporated into the present study.

Previous research in the region on other taxonomic groups such as fishes (Hutchins 1999), echinoderms (Marsh and Marshall 1983) and corals (Veron and Marsh 1988) revealed some general patterns of the fauna in the region. Firstly, species richness and composition were different inshore compared to offshore. Secondly, more endemic species occur inshore compared to more widespread species offshore: we have tested this using data collected by Hanley for the distribution of commensal species of polynoids.

\section{AIMS}

1. Collate records of shallow water $(<30 \mathrm{~m})$ polychaete species in the Kimberley Project Area that are verified by specimens lodged in Australian museum collections (1880s - 2009) to provide a baseline diversity dataset;

2. identify collection and taxonomic bias and gaps;

3. test whether there are proportionally more wide ranging species (e.g. Indo-West Pacific or IndoPacific) occurring offshore compared to inshore - i.e. species that inhabit clear oligotrophic waters versus endemic or Indo-Australian species that would have higher tolerances to the silty turbid waters occurring along the coast; and

4. explore cross shelf differences in species richness and composition for commensal Polynoid species.

\section{METHODS}

The Kimberley Project Area encompasses an area west and north of the Kimberley coast (from south of Broome northward and eastward to the Western Australia-Northern Territory border) extending beyond the $1000 \mathrm{~m}$ bathymetric contour, with the coastline forming a natural inshore boundary, as shown in Figure 1 (see Sampey et al. 2014, for a full explanation of the study area).

For the purpose of this synthesis we are using the classical concept and family membership of the polychaetes (e.g. Fauchald 1977, Rouse and Pleijel 2001). Largely based on molecular data, the clitellates (leeches and oligochaetes), sipunculans, and siboglinids have been moved recently into the polychaetes, but these groups are even less well known from the region. So, while clitellates and sipunculans are widespread and probably diverse in the Kimberley, they are poorly known and will not be considered any further in this review.
The methodology follows that outlined by Sampey et al. (2014). Briefly, polychaete species data were sourced from the collection databases of WAM (July 2010), MAGNT (August 2009) and AM (August 2009), as well as the species reported on WAM survey expeditions of 1988, 1991 and 1994 along the Kimberley coast (Hutchings 1989; Hanley 1992, 1995).

Species names represent a hypothesis that is subject to change as new information (morphology, genetic, behaviour, distribution ranges) is discovered (Gaston and Mound 1993); at this stage all species listed herein are recognised only on the basis of morphological characters (i.e. morphospecies). The species names and taxonomic placement of the records in the dataset were checked in an attempt to present the currently accepted name and to resolve synonymies and old combinations, but the specimens were not re-examined for this study (Sampey et al. 2014). Species names were checked using online databases (Appeltans et al. 2010; ABRS 2011) to identify the currently accepted taxonomic name, and based either on recently published data or research currently being undertaken. However, this does mean that the species names are more up-to-date for some families, and this reflects the current knowledge of Australian polychaetes.

\section{SPATIAL INFORMATION, COLLECTION DETAILS AND MAPPING}

As described in Sampey et al. (2014), data from all sources were collated into a single database. Location and collecting details were checked and verified. The locations of the specimen records were visualised using ARCGIS v9, ArcMap v9.3. Maps of species richness and sampling effort were generated for each main location. Since species richness patterns are highly dependent on sampling effort, we calculated the number of collecting events at a location to provide an indication of relative sampling effort. A collecting event was defined by the season and year of collecting, and the full list of locations, latitude and longitude and other relevant collection information is provided for all taxonomic groups in Table 4 in Sampey et al. (2014).

Throughout this paper 'inshore' refers to locations along the coast, and the numerous islands and reefs found shoreward of the $50 \mathrm{~m}$ depth contour (Figure 1). 'Offshore' refers to the shelf edge atolls, which arise from deeper waters (200-400 m) along the continental margin. 


\section{BIOGEOGRAPHIC AND HABITAT CODING}

Species were coded for their known habitat and biogeographic range (Sampey et al. 2014). If a species did not conform to a single code then appropriate combinations were used.

The following biogeographic codes were used:

- Western Australian endemic (WA). Currently known only from Western Australian waters, often from the type locality only; may eventually prove to be a Northern Australian endemic with more collecting effort.

- Northern Australian endemic (NA). Found throughout tropical Australian waters.

- Southern Australian endemic (SA). Found throughout temperate Australian waters and its presence in the Kimberley is the northern extent of its known range; although this may represent a lack of data and should be treated with caution.

- Australian endemic (A). Found throughout tropical and temperate Australian waters.

- Indo-Australian (IA). Found throughout Australian and Indonesian waters, may extend to the Philippines.

- Indo-West Pacific (IWP). Found throughout the Red Sea, Indian and Western Pacific Oceans.

- Indo-Pacific (IP). Found throughout the Red Sea, Indian Ocean and throughout the Pacific Ocean.

- West Pacific (WP). Found throughout the Western Pacific, although presence in Kimberley indicates its occurrence in at least the eastern Indian Ocean.

- Central Pacific $(\mathrm{CP})^{*}$. Found throughout the Central Pacific.

- Tropicopolitan $(\mathrm{T})^{*}$. Found throughout all tropical oceans.

- Circumglobal $(\mathrm{C})^{*}$. Found throughout all oceans in both tropical and temperate waters.

Codes indicated by an asterisk $\left(^{*}\right)$ are the most problematic and need to be treated with caution; this is especially true for families for which no recent Australian revision has been undertaken. Our knowledge of the distribution and habitat of the polychaete fauna of the Pacific, South East Asia and the Indian Ocean is poor and dominated by widespread species. However, we expect with additional studies, many of these species will be found to consist of several morphologically similar species each with discrete non-overlapping ranges.

Within its distribution range, a species may be restricted to certain habitat types. We provided an indication of the habitats sampled in the Kimberly region to date by coding species for their preferred habitat, if known, as follows:

- Intertidal (i). Found in the intertidal zone, which is extremely large as a result of the large tidal range.

- Subtidal (s). Found in the subtidal or sublittoral zone.

- Hard substrate $(\mathrm{H})$. Found associated with hard substrates (e.g. rock, coral, rubble).

- Soft substrate (S). Found associated with soft substrates (e.g. sand, mud).

- Estuarine (E). Found in estuarine or brackish waters.

- Epizoic (EZ). Always found in an external association with a particular species of animal.

- Unknown (U).

\section{DATA ANALYSES}

To explore composition differences across the shelf, the total number of commensal polynoid species was calculated for each location (reef, island, or atoll) and then visualised using nonmetric multi dimensional scaling (nMDS) using the Bray-Curtis distance measure.

\section{RESULTS}

\section{NUMBER OF SPECIMENS IN COLLECTIONS}

A total of 1,046 registered specimen lots of polychaete species were included in this dataset (excluding lots in overseas museums) (Table 2a). A 'lot' represents between one and many individuals from the same site. The number of lots included was variable across families, ranging from one for 11 families, which usually coincided with that family not being identified to species (e.g. Maldanidae species), to 210 for the Polynoidae, the most consistently collected and identified family in the Project Area (Tables 2 and 3). The number of specimen lots housed in the various institutions was also variable (413 species, 40\%, AM; 588 species, 56\%, MAGNT; and 45 species, $4 \%$, WAM; Table 2).

Many lots were excluded from the present dataset (814 species, $44 \%$; Table 2 b). This was primarily due to incomplete identification or where the records are not consistent with any recognisable nomenclature. This material needs to be re-examined. Three lots were collected in waters deeper than $30 \mathrm{~m}$. A further 125 lots of polychaetes are available in WAM, but these were not included in the dataset due to late cataloguing of samples.

The oldest Kimberley polychaete record housed in 
collections of Australian museums was Myzostoma stochoeides Atkins, 1927, taken off crinoids collected by H.L. Clark at Cape Villaret in 1929 and housed in the AM collections. A number of species, including Perkinsyllis augeneri (Hartmann-Schröder, 1979) collected by Hartmann-Schröder at Broome in 1975, are located in the collections of WAM. The oldest MAGNT Kimberley specimen was Platynereis uniseris Hutchings and Reid, 1991 collected from Ashmore Reef in 1983. This reflects the dearth of collecting in the Kimberley region from the early 1900 s to the late 1970s.

Up to 2009, 30 new polychaete species have been described from the Kimberley, belonging to eight families (Capitellidae, Glyceridae, Nereididae, Phyllodocidae, Pilargidae, Serpulidae, Syllidae, and Terebellidae). In addition, several new species and genera of Polynoidae in the MAGNT collection have been flagged as new by R. Hanley, but have yet to be formerly described (Table 3). Work is underway by M. Capa and C. Watson (MAGNT) describing new species of Sabellidae and Chrysopetalidae, respectively. It is anticipated that future collecting events in the Project Area will yield many more new species and records of polychaetes for the area.

\section{SPECIES RICHNESS AND COLLECTING EFFORT}

A total of 261 taxa belonging to 43 families of polychaetes were recorded in our dataset (Table 3). Sixteen families have not yet been sorted to morphospecies: Euphrosinidae, Lumbrineridae, Nephtyidae, Sphaerodoridae, Maldanidae, Opheliidae, Orbiniidae, Paraonidae, Questidae, Scalibregmatidae, Chaetopteridae, Magelonidae, Poecilochaetidae, Spionidae, Ampharetidae, and Flabelligeridae (Table 3). In part this reflects the lack of expertise in these families worldwide, although some are currently being investigated, and this paper may help to alert the worldwide polychaete community to the availability of this material for study.

Polychaete data are available for 69 locations in the Project Area (Table 4, Figures 1-3). Species richness ranged from 80 (at Broome) to one (at 12 inshore and one offshore location; Table 4, Figure 2). Collecting effort was highly variable, with nine collecting events occurring at Broome, but only one at 48 other locations (Table 4, Figure 3). The number of polychaete families collected at any one location was also highly variable with 29 families collected at Broome compared to only one family at 16 other locations (Table 4). The presence or absence of polychaete families reported at a location very much depends on the habitats sampled and the collector. More polychaete species have been reported from inshore (232 species) than offshore (82 species; Tables 3, 6 and 7). However, collecting effort is substantially different for these areas of the shelf, with more collecting inshore compared to offshore or midshelf (25 versus 13 locations, respectively). At the time of writing, no collecting had occurred at Browse Island (midshelf) for polychaetes. The eastern Kimberley has not been sampled for polychaetes, nor have Seringapatam or Imperieuse Reef (Rowley Shoals) (Figure 1). The Polynoidae is likely to have had a more even collecting effort than others (see Discussion) and of the 33 species total, 27 are reported from inshore sites, 21 from offshore sites and 15 occurred in both. There is a weak inshore versus offshore difference in species composition (MDS plot, Figure 4), which may be explained partially because many species recorded here are commensal on echinoderms, which show a similar inshore versus offshore difference in both richness and composition (Sampey and Marsh 2015).

\section{BIOGEOGRAPHY AND HABITATS}

The majority of polychaete species were widespread (in all categories C, CP, IA, IP, IWP, T, WP) both inshore (111 species, $49 \%$ ) and offshore (45 species, $54 \%$ ) (Table 5).

The proportion of endemics (those in categories WA, A, NA and SA) inshore (87 species, 38\%) was more than twice the proportion of endemics offshore (12 species, 14\%) (Table 5). The proportion of Indo-Australian species was also higher inshore (20 species, 9\%) versus offshore (5 species, 6\%) (Table 5). The dominance of widely distributed species is also reflected in the Polynoidae. In this family one, and possibly up to four, species are narrow range endemics (Australaugeneria michaelseni Pettibone, 1969). Three new undescribed taxa identified by Hanley (Table 3, Figure 1, 2), and another three polynoid species occur in the Kimberley as well as in other parts of Australia. Twenty five species of polynoids found in the Kimberley also occur throughout the Indo-West Pacific region.

A high proportion of the species were associated with hard substrates: 70 species (31\%) inshore versus 19 species $(23 \%)$ offshore. However, some species were associated with soft substrates (41 species, 18\% inshore versus 4 species, $5 \%$ offshore, Table 6 ). Three species were estuarine (Table 6). Most species had an unknown substrate preference (72 species, 34\% inshore versus 27 species, 32\% offshore; Table 6). However, it should be noted that many families not represented are those that live exclusively buried in soft sediments, which were not sampled. 


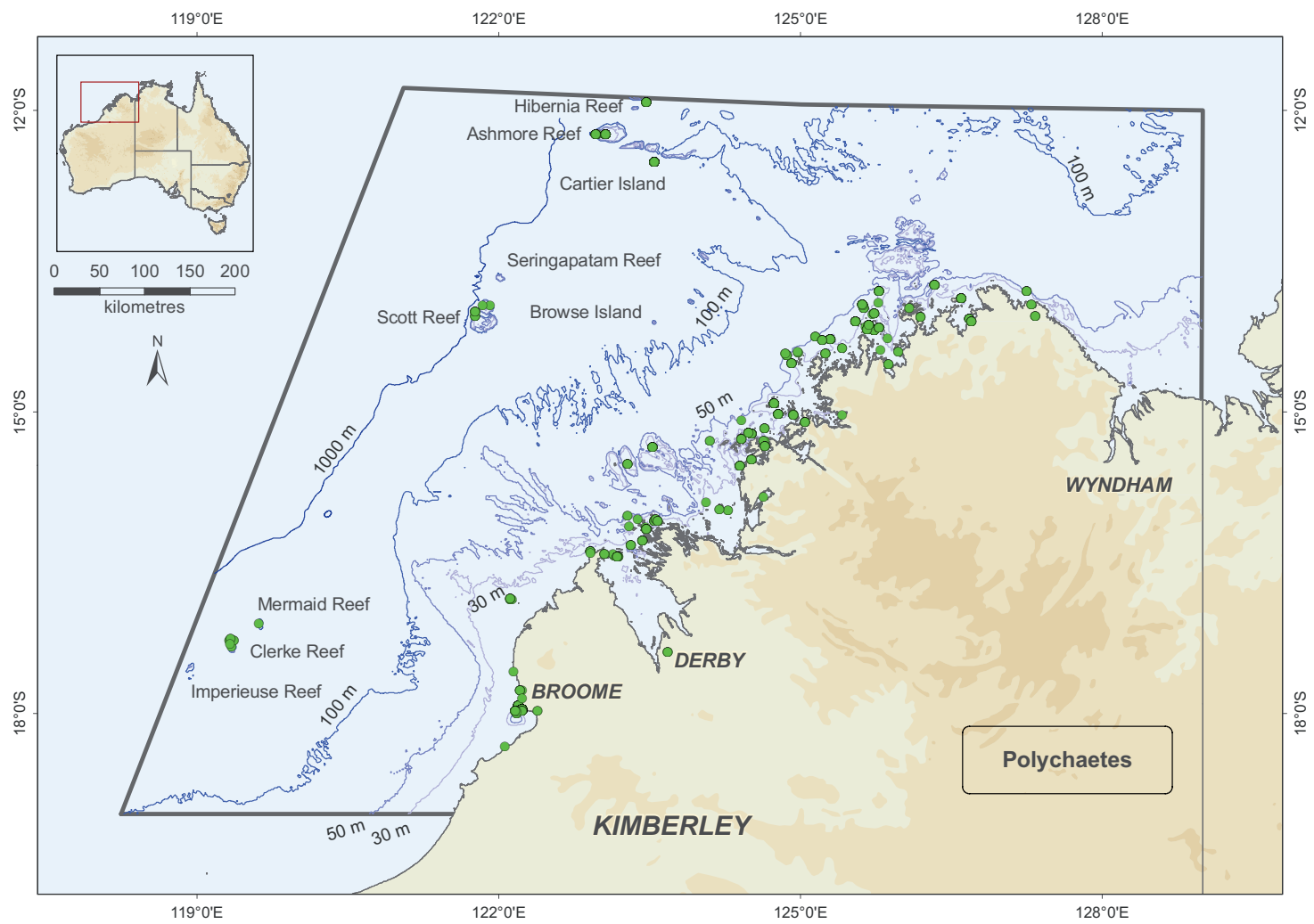

FIGURE $1 \quad$ Location of records of polychaete species in the Kimberley Project Area of Western Australia. The Project Area boundary is marked in grey. Map projection: GDA94, Scale: 1:6, 250,000.

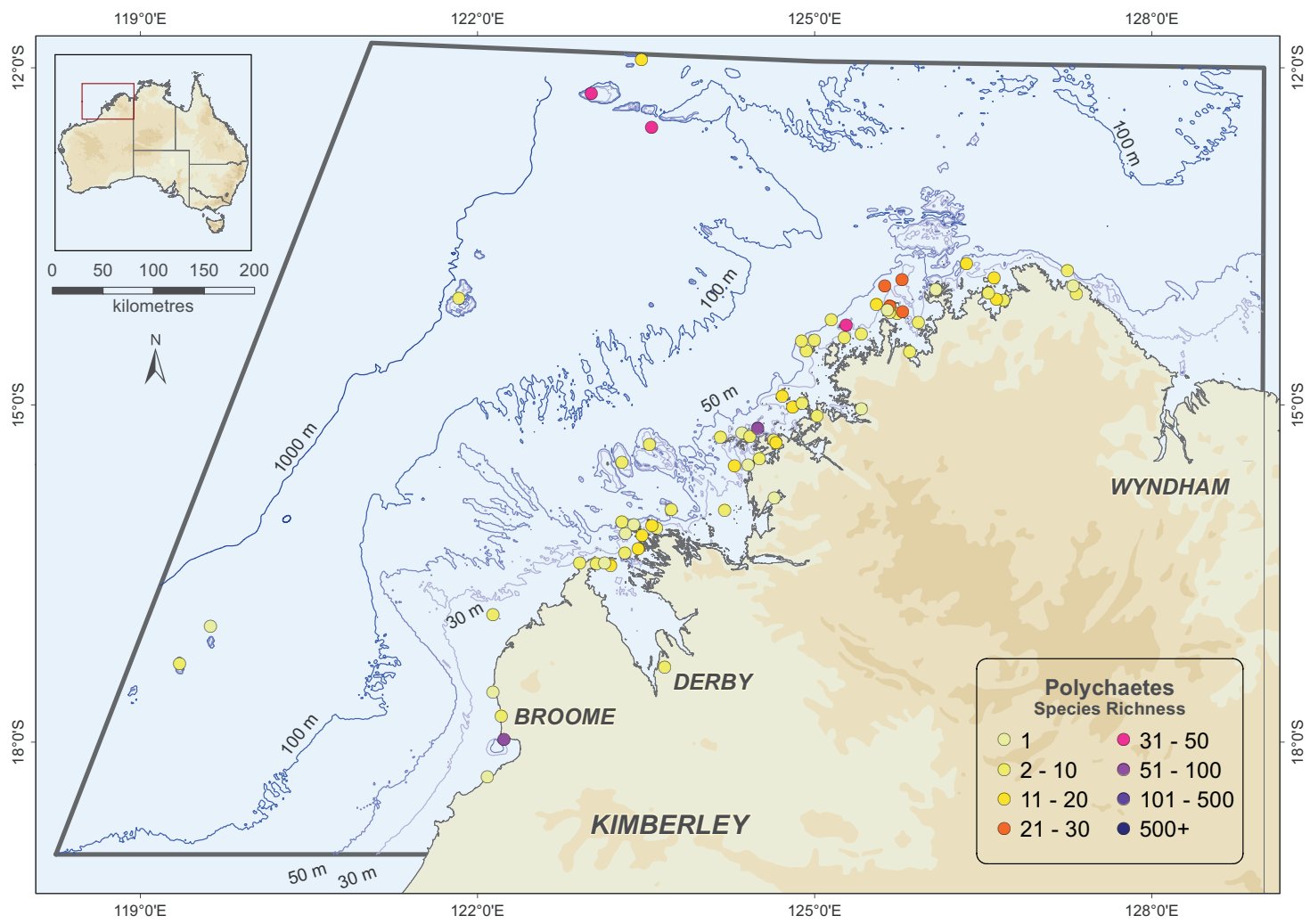

FIGURE 2 Species richness of polychaetes for each main location. Map projection: GDA94, Scale: 1:6, $250,000$. 


\section{DISCUSSION}

These results demonstrate that the polychaete fauna of the Project Area remains largely under sampled and undescribed. Collection gaps are methodological since the sampling effort has been concentrated mostly in shallow water hard substrates. Sampling across the shelf, including soft sediments between reefs, certainly would reveal a highly diverse polychaete assemblage. The data are also biased towards larger species, and fine sorting of soft sediments and washings from broken up hard substrates would yield additional species. Further, existing collections reflect surveys that were inventory focussed and somewhat biased toward certain families, which were the interest of the particular workers undertaking the collecting (e.g. Polynoidae).

Identification efforts have been greatest on certain families (e.g. Nereididae, Terebellidae, Polynoidae), which have been the subject of recent taxonomic research. Within the WAM, AM and MAGNT collections there are unidentified polychaetes, some sorted to family and included in this study, others not. This highlights the lack of funding for taxonomic research and the lack of taxonomic expertise in particular polychaete families. Nevertheless, some of this material (e.g. Sabellidae, Sabellariidae, Oweniidae) is currently being examined with new species to be described. We also anticipate that some of these specimens will be found to represent species endemic to the areas.

It is premature to make any generalisations about the polychaete fauna of the Project Area as so much is still unknown. Our discussion focuses on what is known from the limited families studied to date and highlights some collection and taxonomic gaps, which will provide a basis to focus future research.

\section{SPECIES RICHNESS PATTERNS}

The 261 taxa listed in our dataset represent a low species richness estimate of polychaetes for the Project Area if compared to other tropical areas (Hutchings personal observation). Causes for this low diversity are the limited collecting effort mentioned above together with the superficial identification of specimens of particular families.

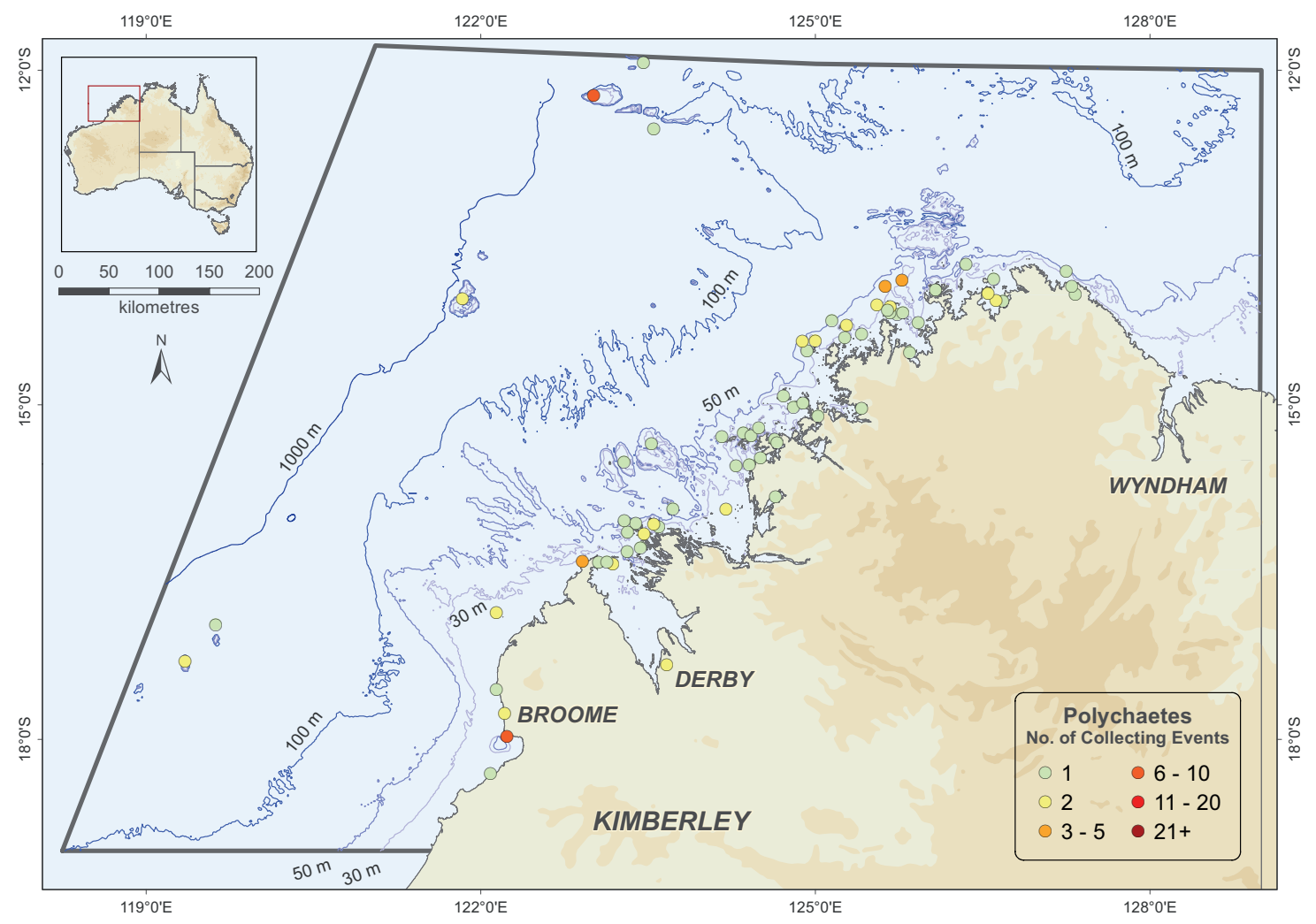

FIGURE 3 Number of collecting events for polychaetes at each main collecting location. This was based on a count of the season code and provides an indication of sampling effort. Map projection: GDA94, Scale: 1:6, 250,000. 
TABLE 2 Number of registered specimen lots of Kimberley polychaetes housed in Australian natural history collections. Included are those lots identified to species or able to be distinguished as a separate species. Excluded lots are those that were incompletely identified or from deepwater (>30 m) locations.

\begin{tabular}{|c|c|c|c|c|c|c|c|c|c|}
\hline Included families & AM & MAGNT & WAM & Total & Excluded families & AM & MAGNT & WAM & Total \\
\hline Acoetidae & & 2 & & 2 & Acoetidae & & 1 & & 1 \\
\hline Ampharetidae & & 1 & & 1 & Amphinomidae & & 25 & 4 & 29 \\
\hline Amphinomidae & 1 & 5 & & 6 & Aphroditidae & & 1 & 1 & 2 \\
\hline Aphroditidae & 4 & 2 & 1 & 7 & Arenicolidae & & & 2 & 2 \\
\hline Capitellidae & & & 1 & 1 & Capitellidae & & 33 & & 33 \\
\hline Chaetopteridae & & 19 & & 19 & Chrysopetalidae & 3 & 53 & & 56 \\
\hline Chrysopetalidae & 29 & 5 & & 34 & Cirratulidae & & 27 & & 27 \\
\hline Cirratulidae & & 1 & & 1 & Dorvilleidae & & 5 & & 5 \\
\hline Dorvilleidae & 1 & & & 1 & Eunicidae & 1 & 96 & 2 & 99 \\
\hline Eunicidae & 2 & 28 & & 30 & Euphrosinidae & & 3 & & 3 \\
\hline Euphrosinidae & & 1 & & 1 & Glyceridae & & 16 & 1 & 17 \\
\hline Flabelligeridae & & 5 & & 5 & Hesionidae & & 23 & 1 & 24 \\
\hline Glyceridae & & 11 & 1 & 12 & Lumbrineridae & & 26 & & 26 \\
\hline Goniadidae & 4 & 1 & & 5 & Myzostomidae & 1 & & & 1 \\
\hline Hesionidae & & 11 & & 11 & Nereididae & 2 & 80 & 13 & 95 \\
\hline Lumbrineridae & & 2 & & 2 & Oenonidae & & 16 & & 16 \\
\hline Magelonidae & & 1 & & 1 & Onuphidae & 2 & 2 & 3 & 7 \\
\hline Maldanidae & & 9 & & 9 & Oweniidae & & 4 & 1 & 5 \\
\hline Myzostomidae & 1 & & 12 & 13 & Pectinariidae & & & 1 & 1 \\
\hline Nephtyidae & & 7 & & 7 & Phyllodocidae & & 26 & & 26 \\
\hline Nereididae & 70 & 54 & 16 & 140 & Pilargidae & & 3 & & 3 \\
\hline Oenonidae & & 1 & & 1 & Polynoidae & 30 & 71 & 2 & 103 \\
\hline Onuphidae & 3 & 4 & & 7 & Sabellariidae & & 4 & 1 & 5 \\
\hline Opheliidae & & 26 & & 26 & Sabellidae & 6 & 32 & 1 & 39 \\
\hline Orbiniidae & & 14 & & 14 & Serpulidae & 24 & 14 & 2 & 40 \\
\hline Oweniidae & & 9 & & 9 & Sigalionidae & & 7 & & 7 \\
\hline Paraonidae & & 2 & & 2 & Syllidae & 12 & 84 & & 96 \\
\hline Pectinariidae & 1 & & 1 & 2 & Terebellidae & 1 & 45 & & 46 \\
\hline Phyllodocidae & & 10 & 1 & 11 & Total & 82 & 697 & 35 & 814 \\
\hline Pilargiidae & & & 1 & 1 & & & & & \\
\hline Poecilochaetidae & & 2 & & 2 & & & & & \\
\hline Polynoidae & 4 & 206 & & 210 & & & & & \\
\hline Questidae & & 1 & & 1 & & & & & \\
\hline Sabellariidae & 1 & & 1 & 2 & & & & & \\
\hline Sabellidae & 31 & 8 & & 39 & & & & & \\
\hline Scalibregmatidae & & 3 & & 3 & & & & & \\
\hline Serpulidae & 96 & 45 & 1 & 142 & & & & & \\
\hline Sigalionidae & 1 & 2 & & 3 & & & & & \\
\hline Sphaerodoridae & 1 & & & 1 & & & & & \\
\hline Spionidae & & 14 & & 14 & & & & & \\
\hline Syllidae & 75 & 11 & 6 & 92 & & & & & \\
\hline Terebellidae & 88 & 64 & 3 & 155 & & & & & \\
\hline Trichobranchidae & & 1 & & 1 & & & & & \\
\hline Total & 413 & 588 & 45 & 1046 & & & & & \\
\hline
\end{tabular}




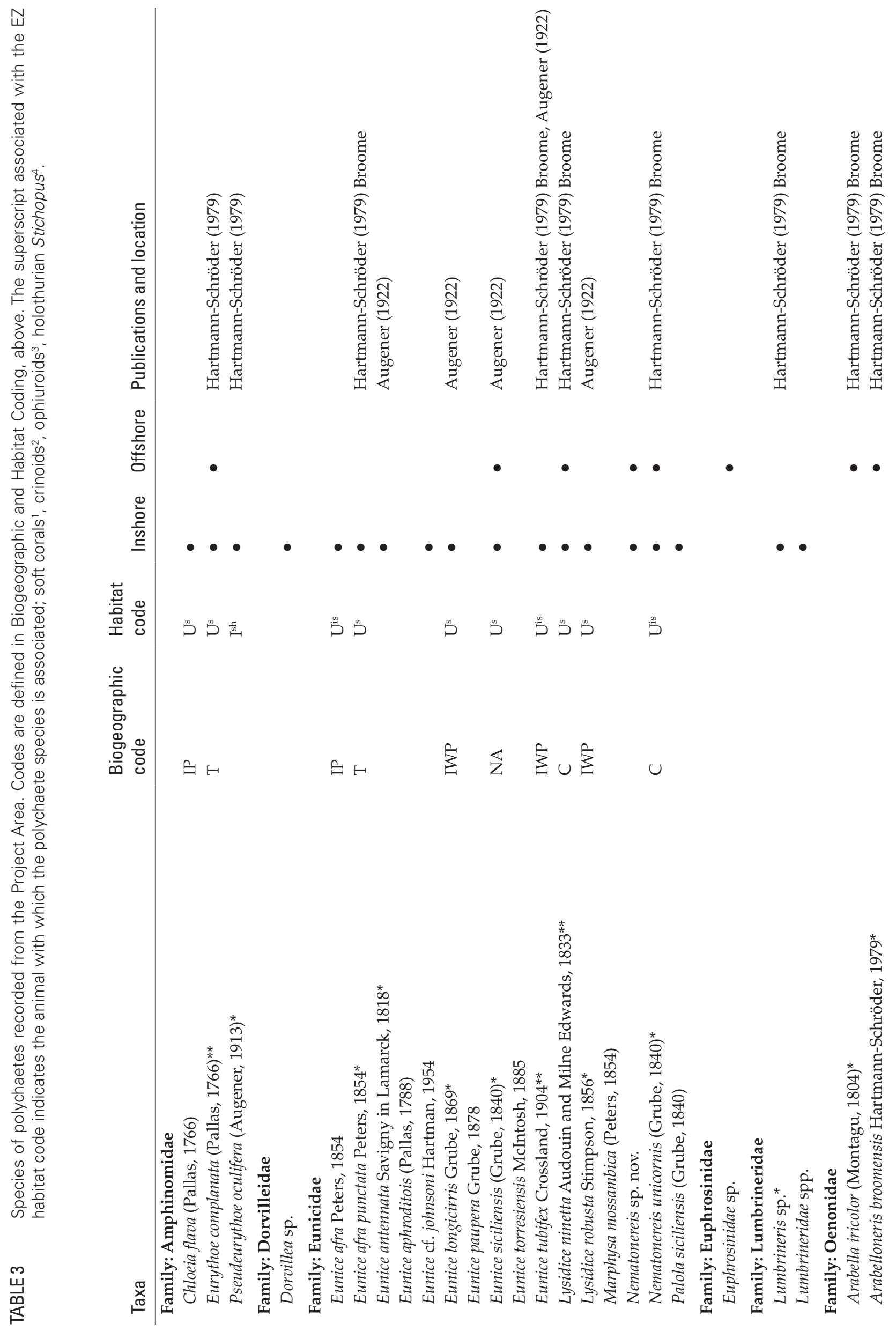




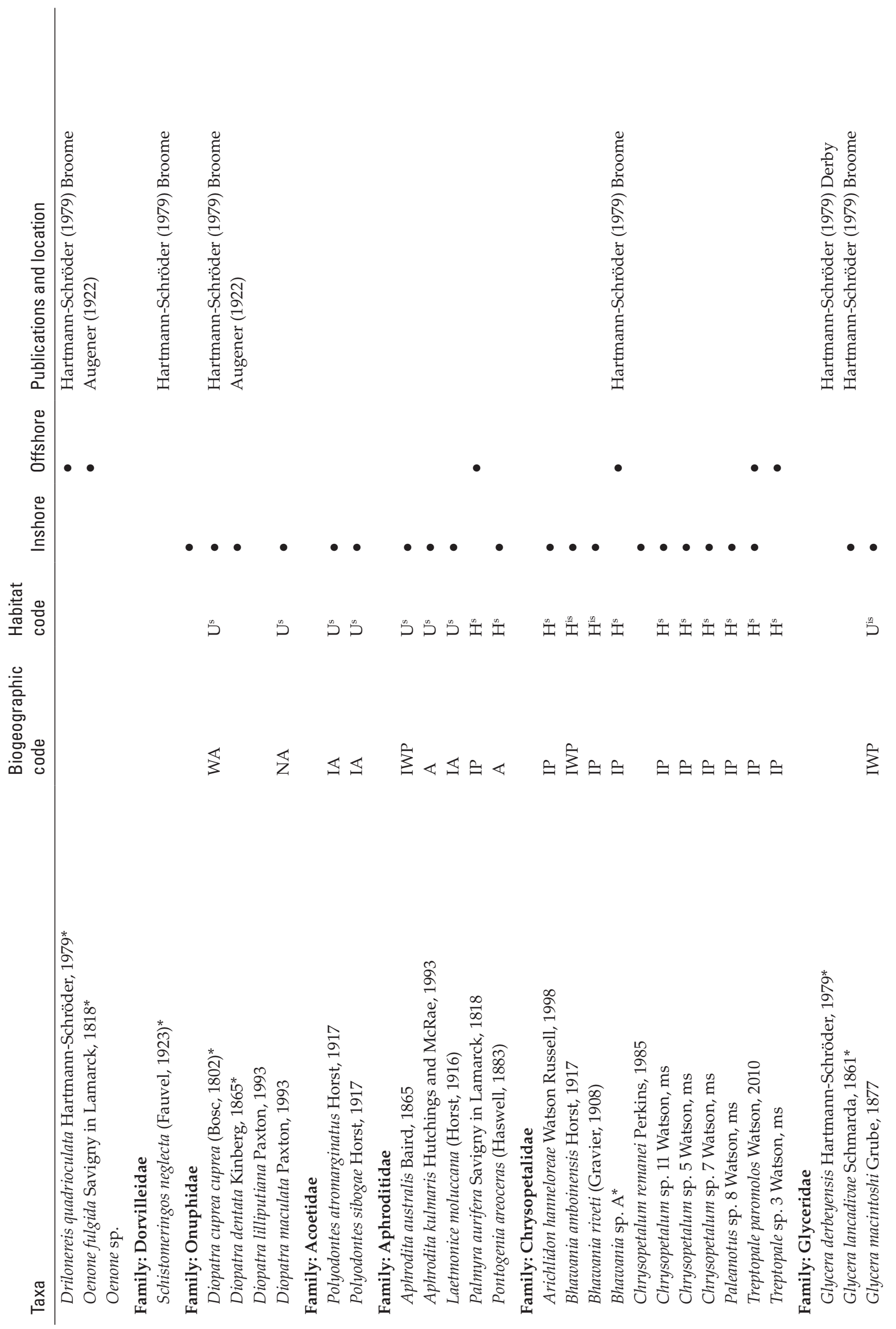




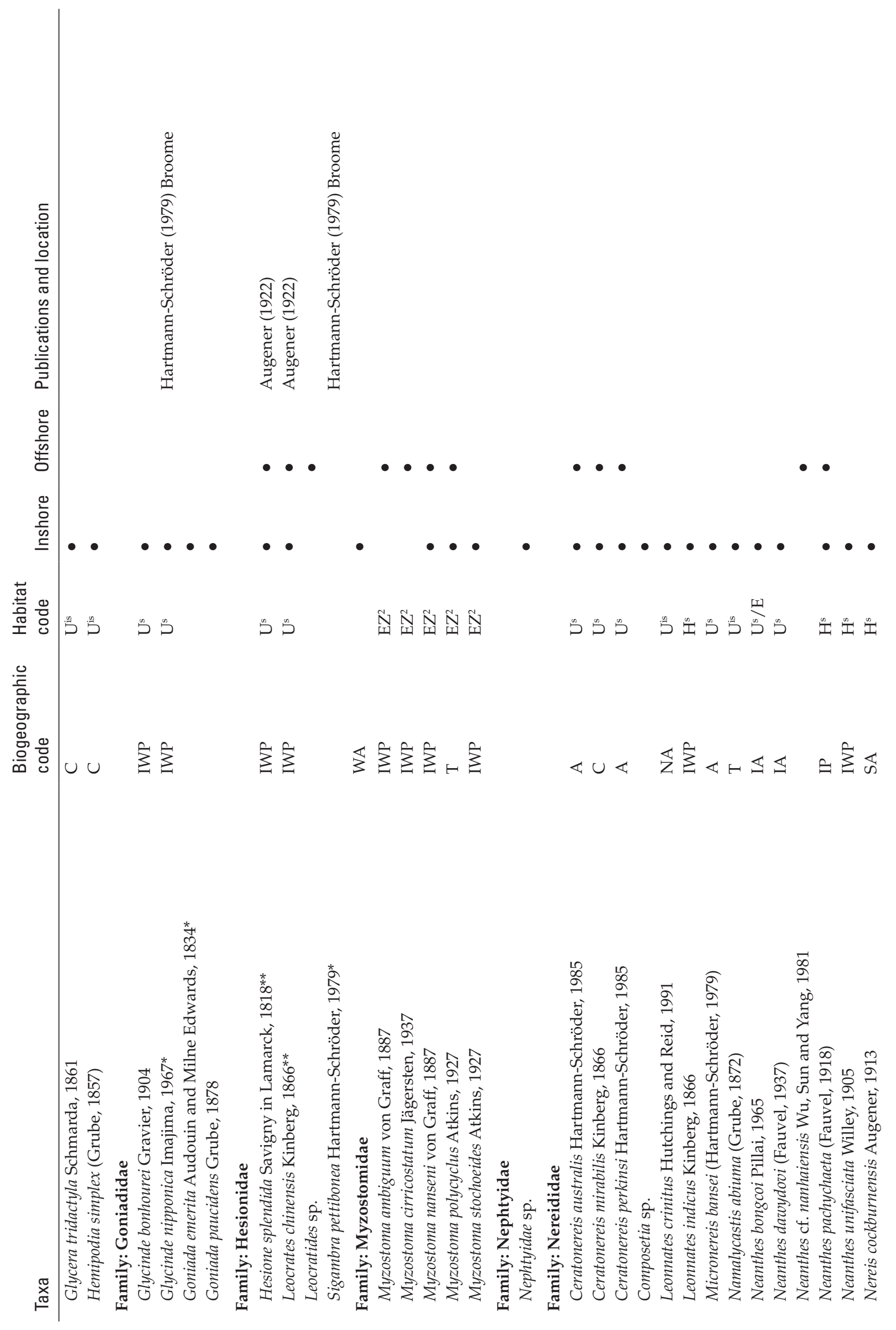




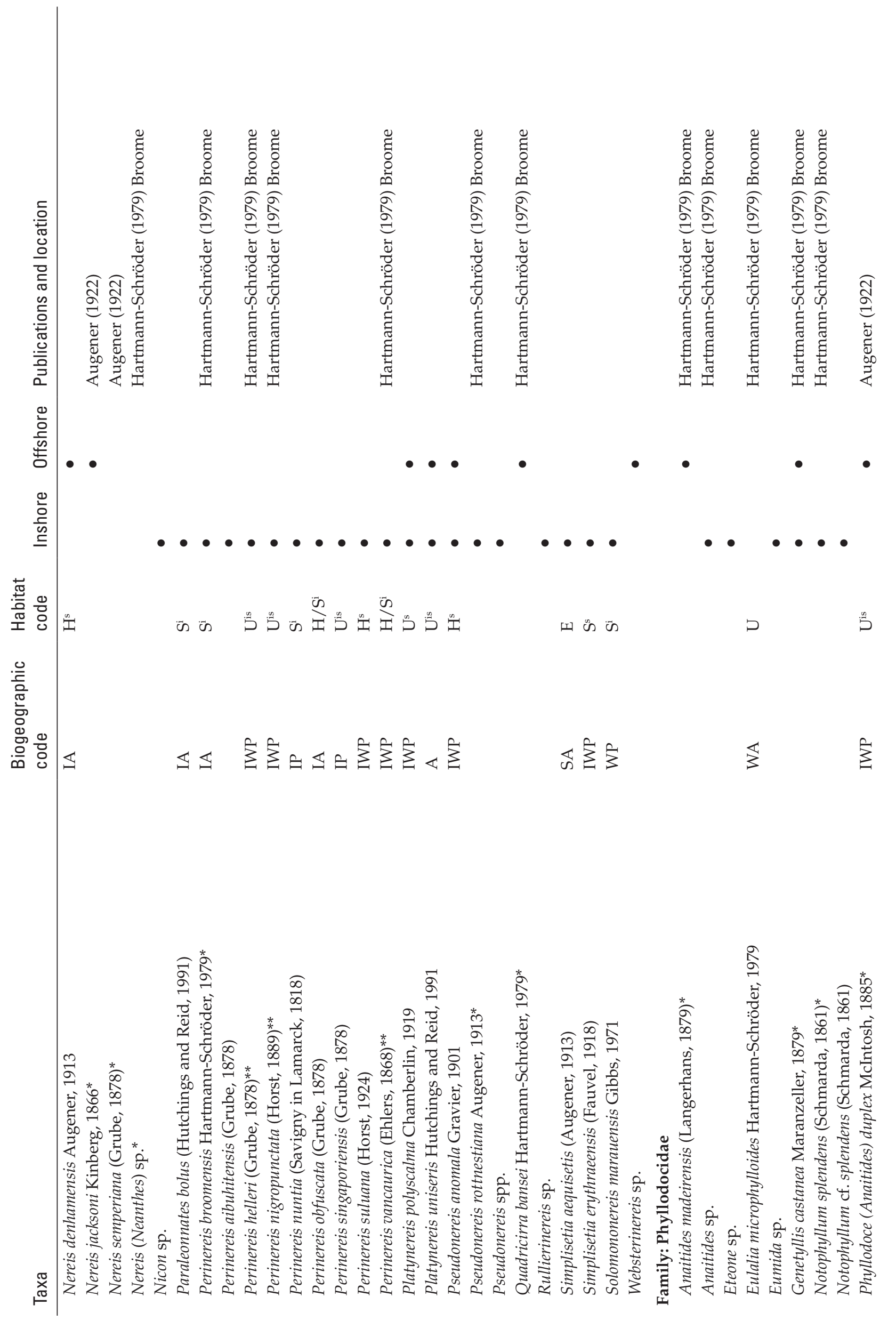




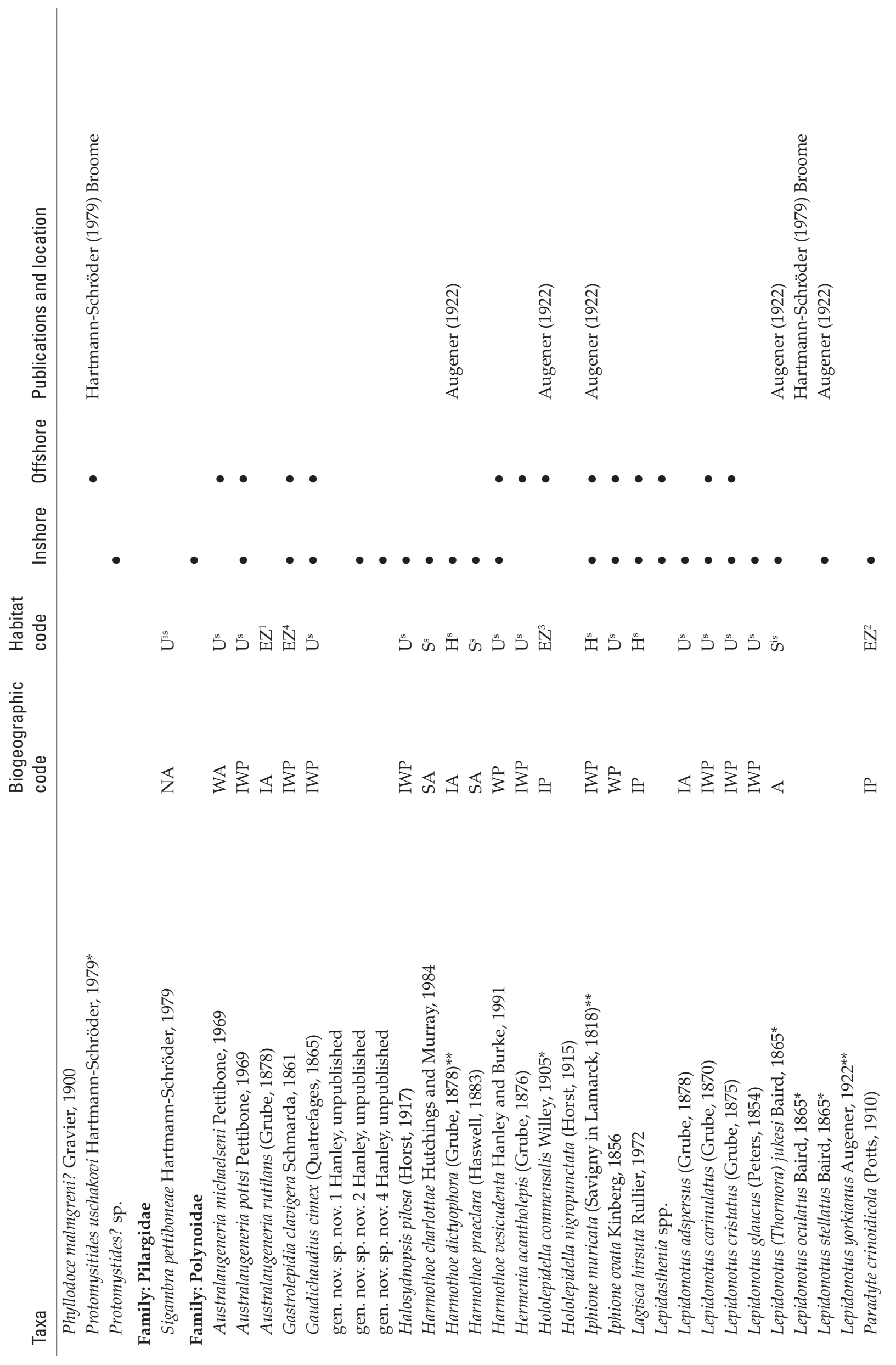




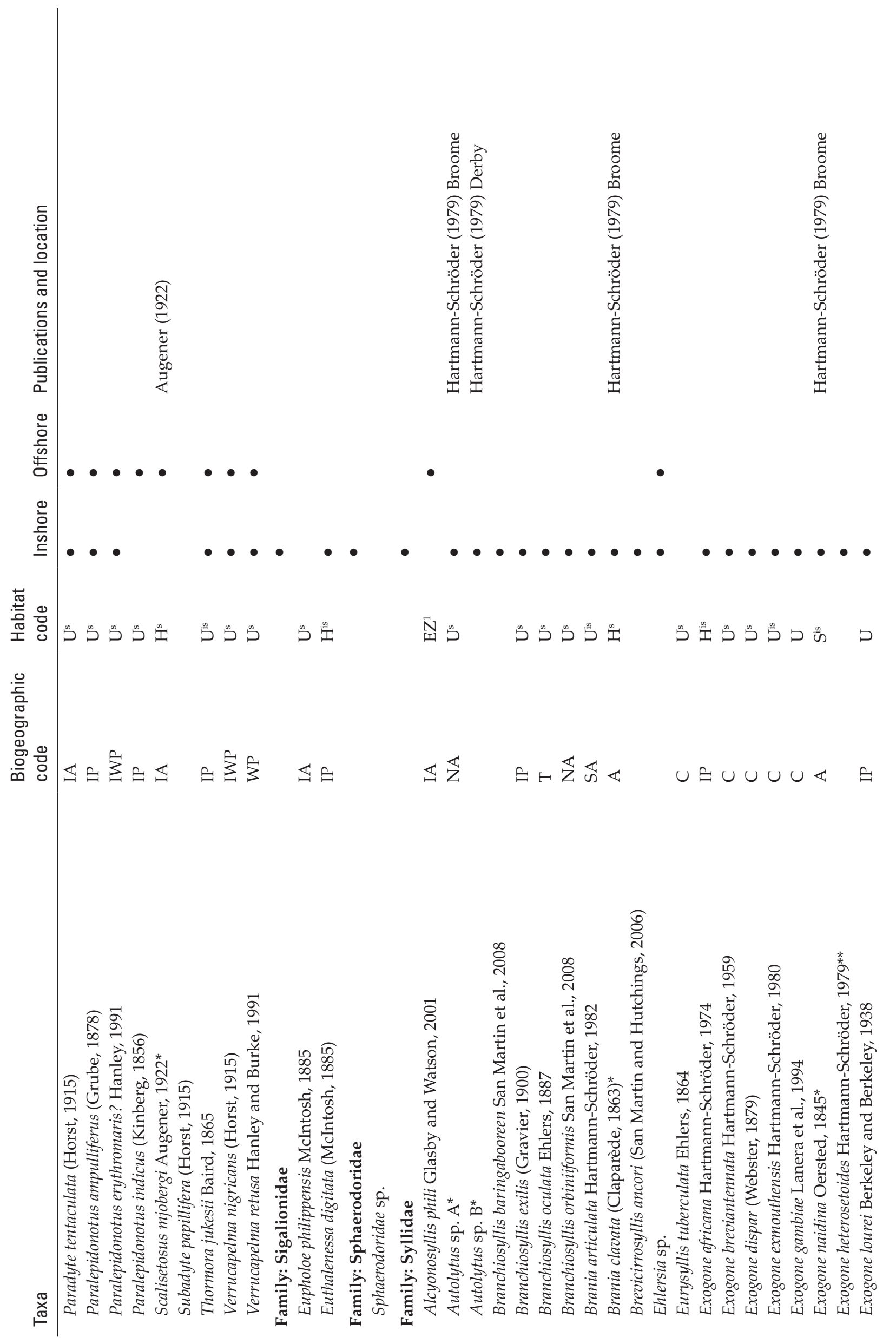




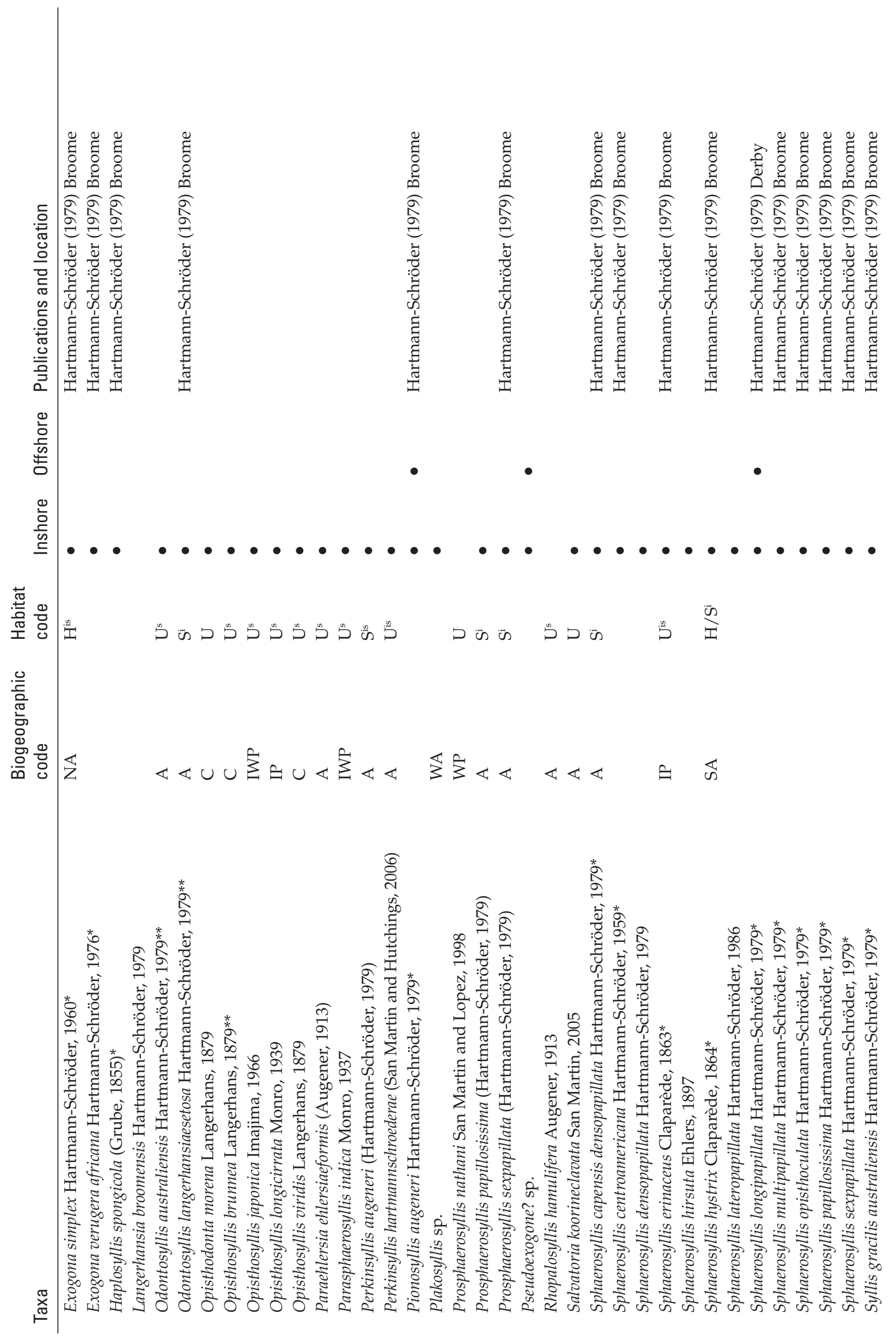




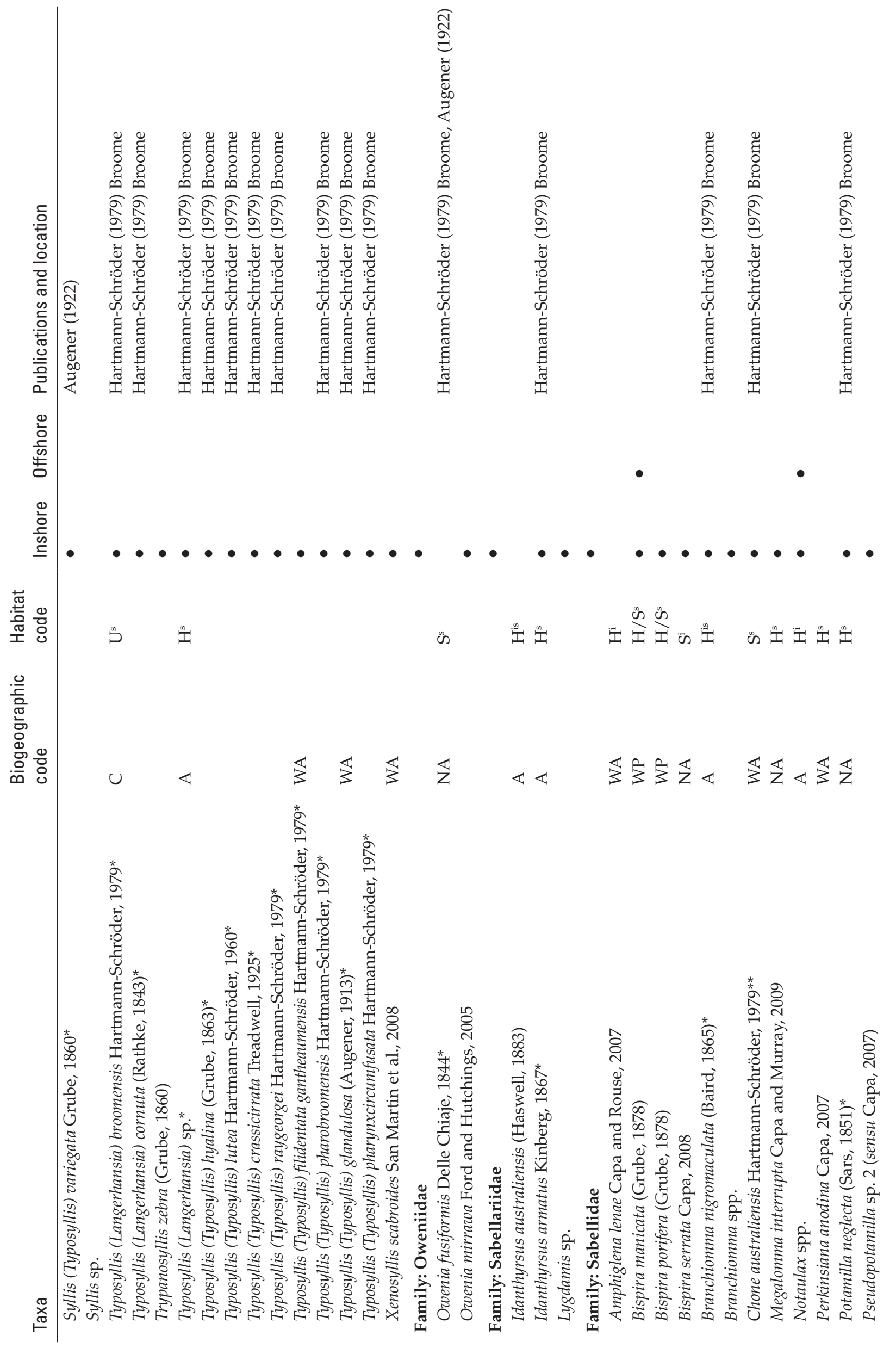




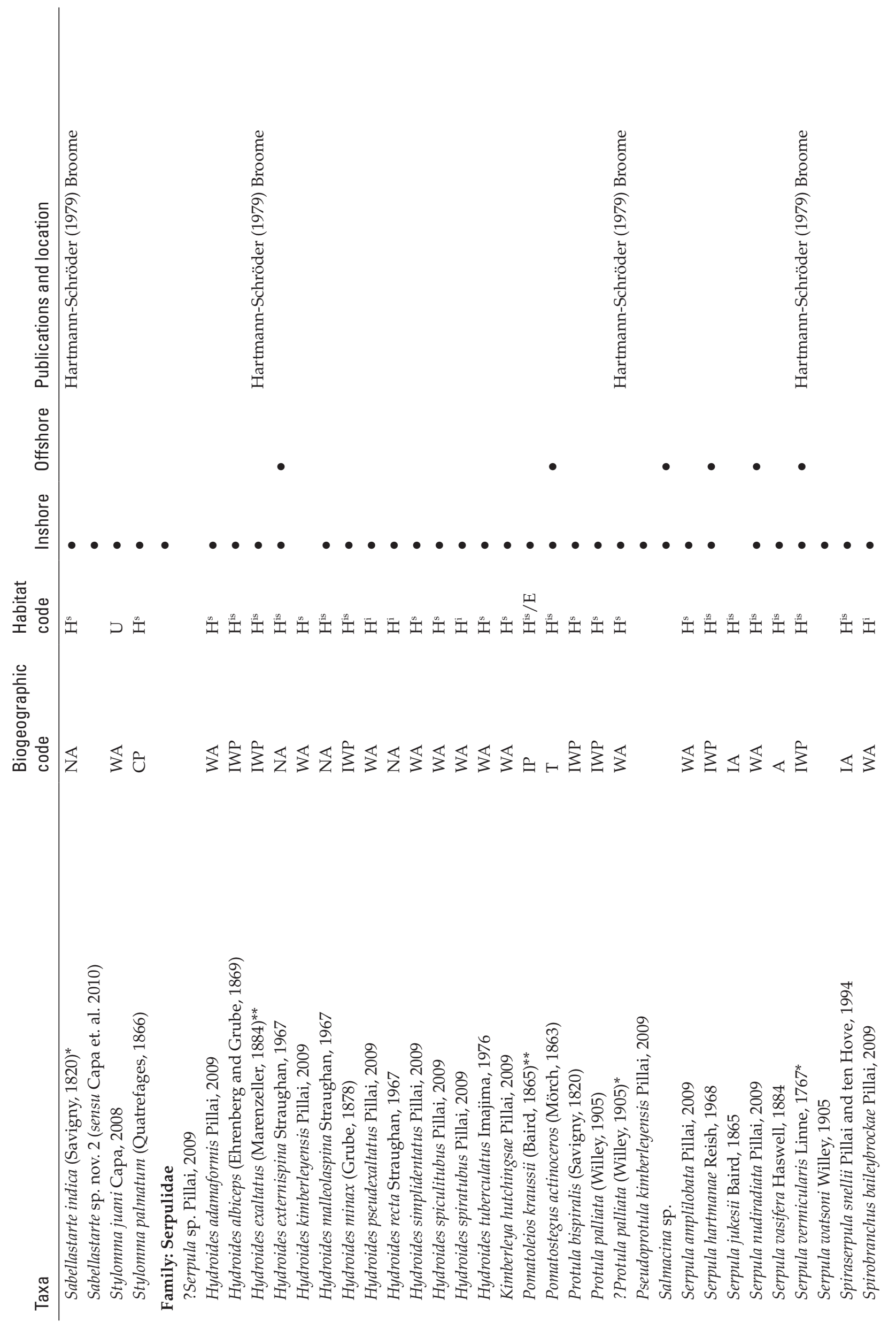




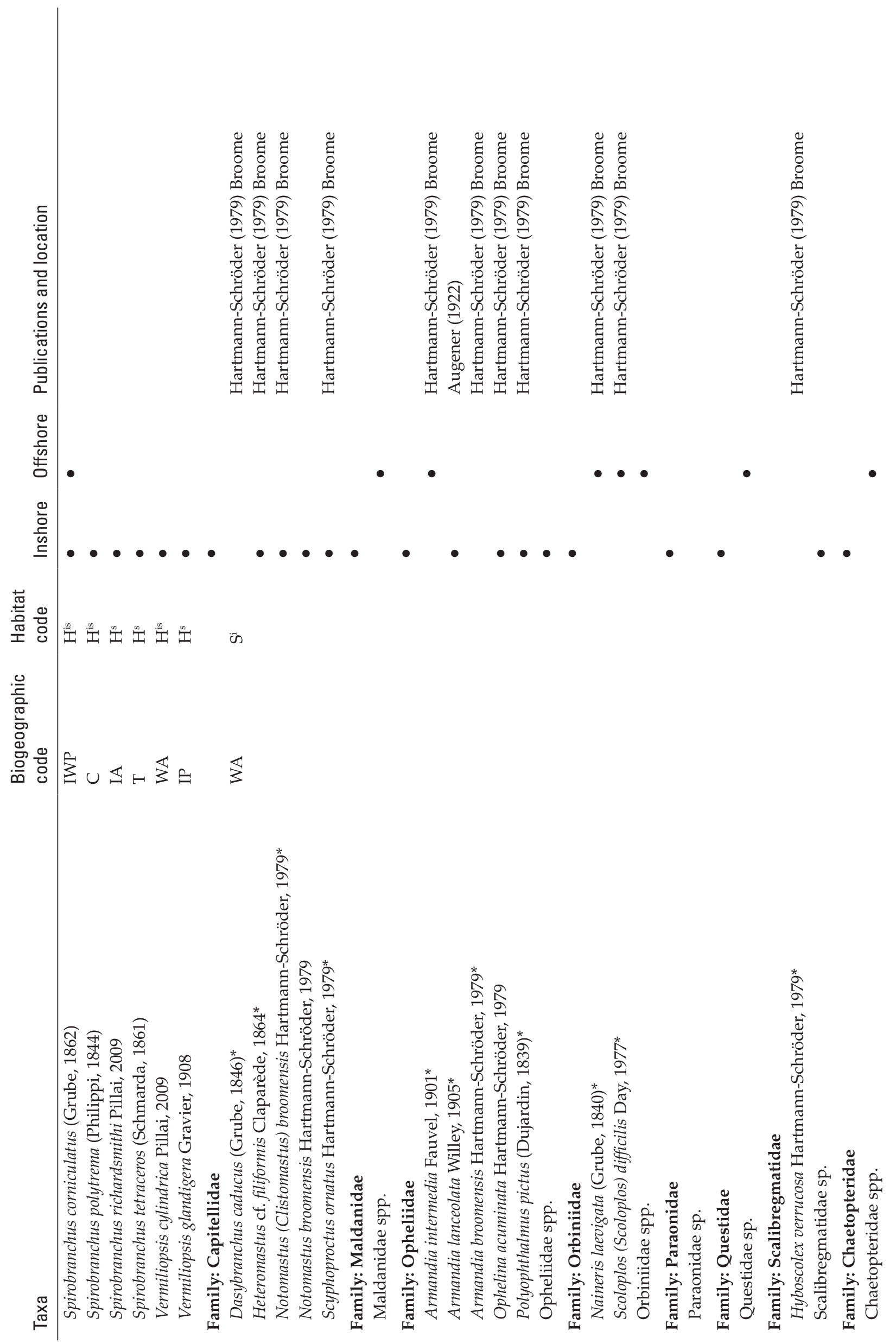




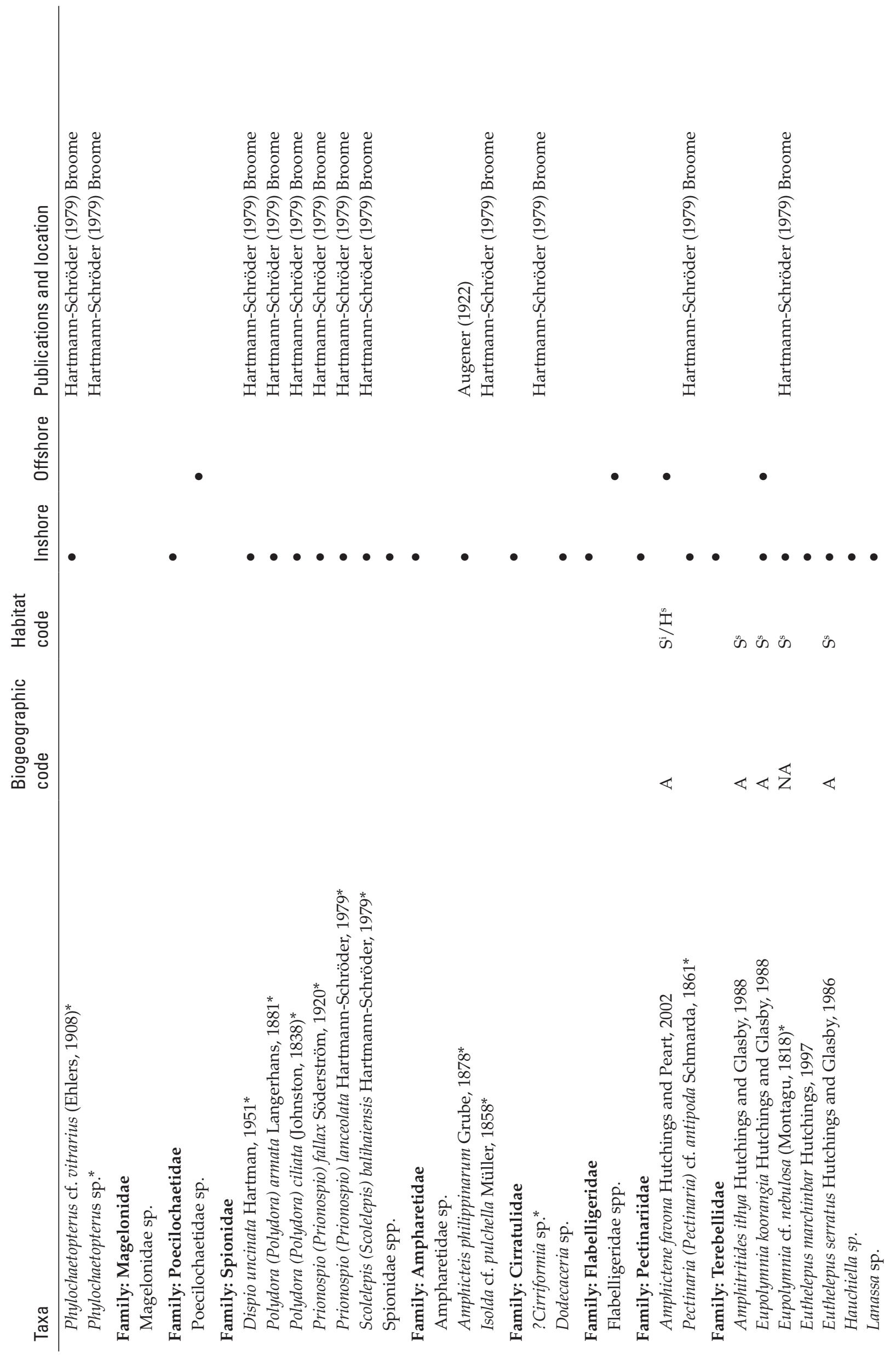




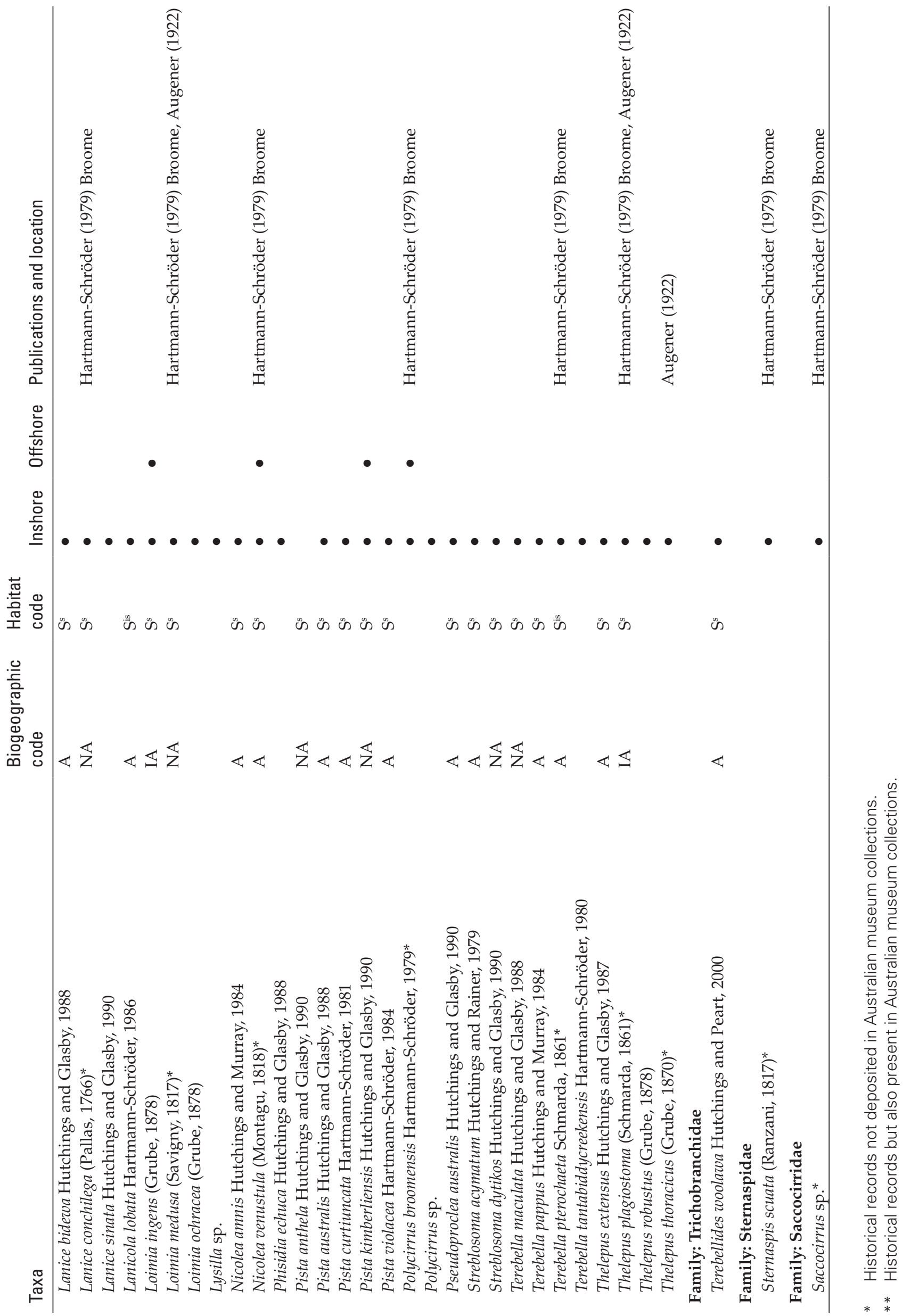




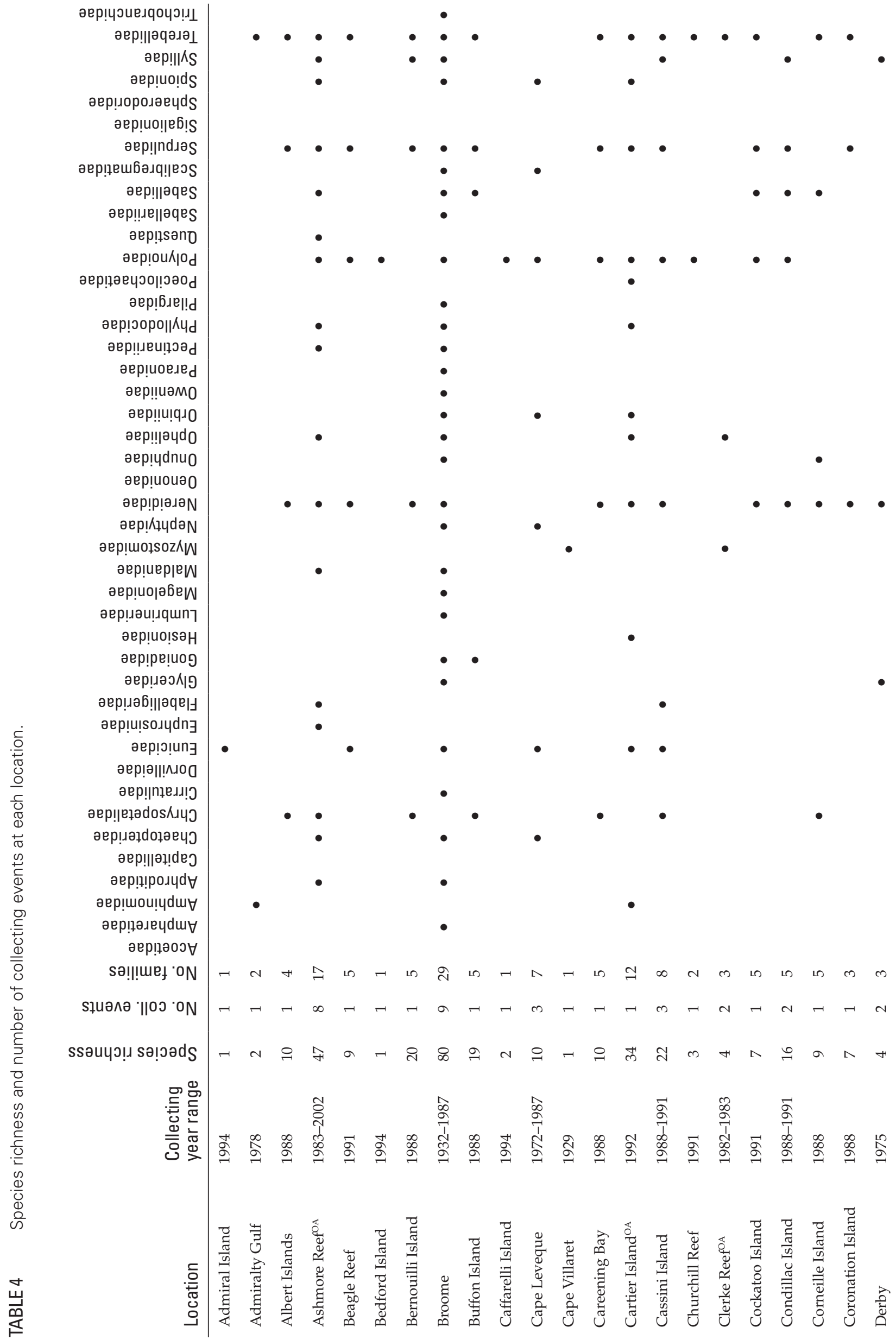




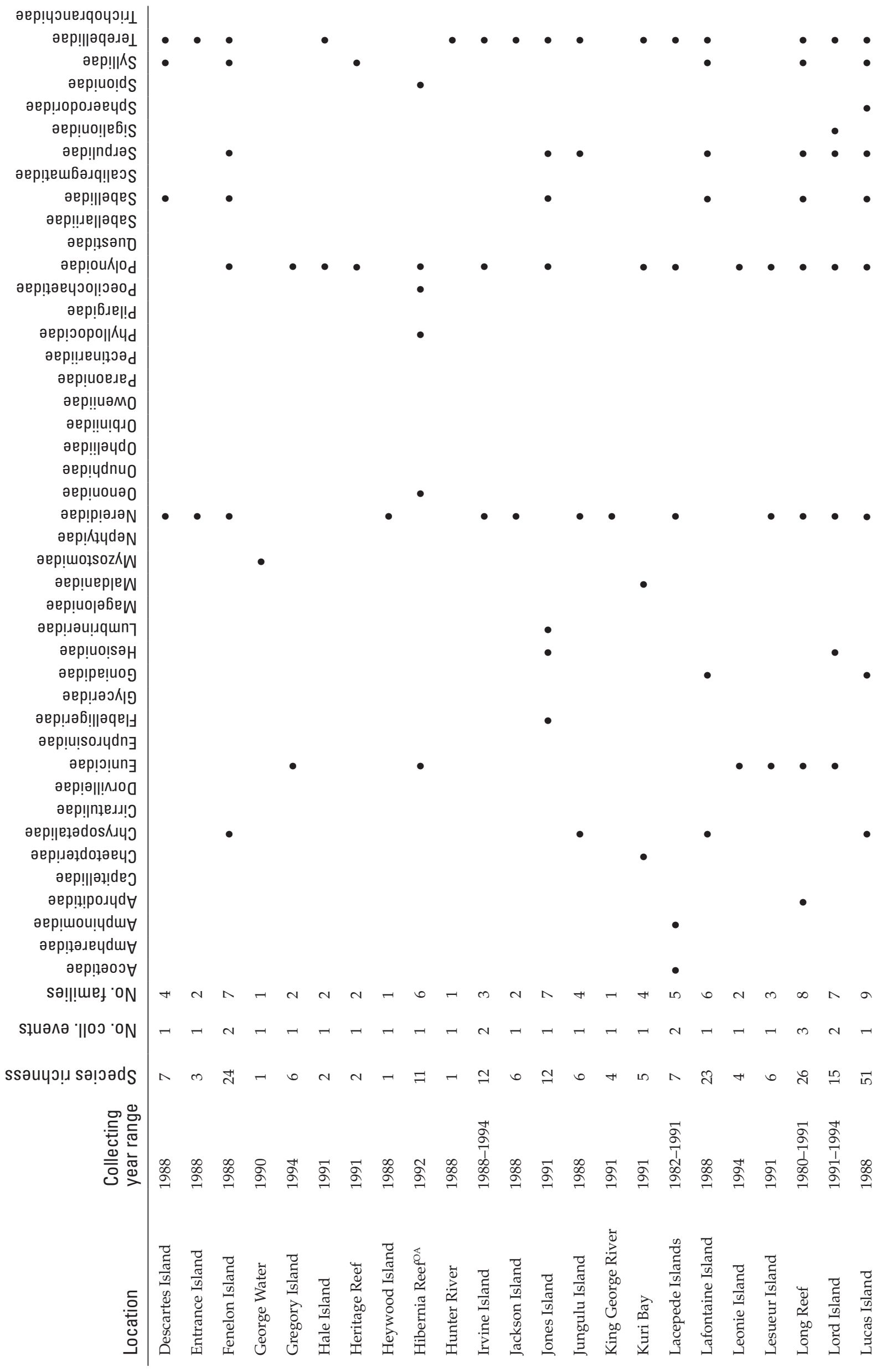




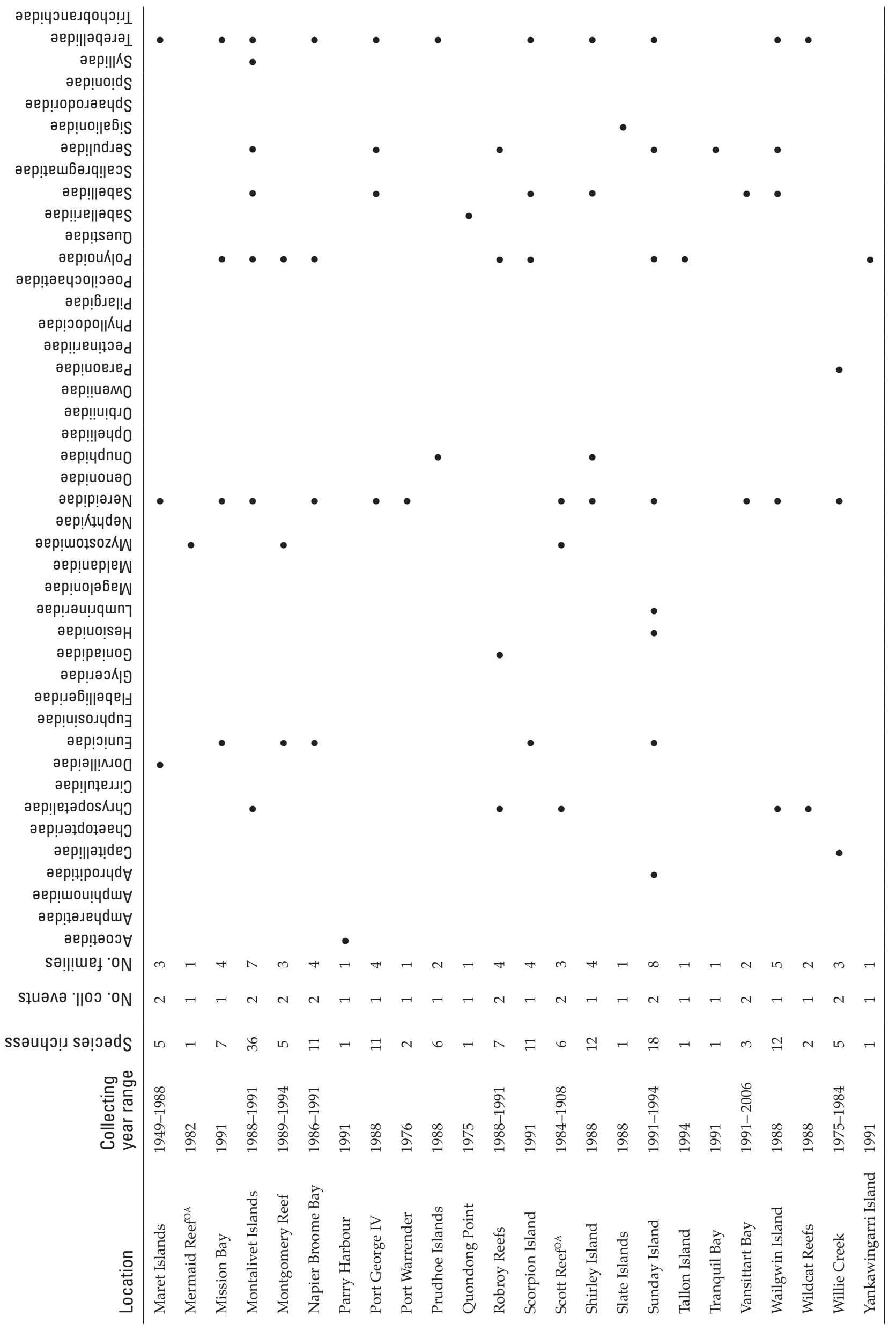


TABLE 5 Species richness and number of collecting events at each location.

\begin{tabular}{lrr} 
Biogeographic Code & Inshore & Offshore \\
\hline- & 30 & 27 \\
A & 40 & 7 \\
WA & 20 & 2 \\
NA & 21 & 3 \\
SA & 6 & \\
C & 15 & 3 \\
CP & 1 & \\
IA & 20 & 5 \\
IP & 25 & 10 \\
IWP & 37 & 20 \\
T & 7 & 3 \\
WP & 6 & 4 \\
Total & 228 & 84 \\
\hline
\end{tabular}

TABLE 6 Number of species with each habitat code.

\begin{tabular}{|c|c|c|}
\hline Habitat Code & Inshore & Offshore \\
\hline- & 30 & 27 \\
\hline E & 1 & \\
\hline $\mathrm{EZ}$ & 8 & 7 \\
\hline $\mathrm{H}^{\mathrm{i}}$ & 5 & 1 \\
\hline $\mathrm{H}^{\mathrm{i}} / \mathrm{S}^{\mathrm{i}}$ & 3 & \\
\hline $\mathrm{H}^{\text {is }}$ & 20 & 6 \\
\hline $\mathrm{H}^{\text {is }} / \mathrm{E}$ & 1 & \\
\hline $\mathrm{H}^{\mathrm{s}}$ & 38 & 10 \\
\hline $\mathrm{H}^{\mathrm{s}} / \mathrm{S}^{\mathrm{i}}$ & 1 & 1 \\
\hline $\mathrm{H}^{\mathrm{s}} / \mathrm{S}^{\mathrm{s}}$ & 2 & 1 \\
\hline$S^{i}$ & 10 & \\
\hline$S^{\text {is }}$ & 5 & \\
\hline$S^{s}$ & 26 & 4 \\
\hline $\mathrm{U}$ & 6 & \\
\hline $\mathrm{U}^{\text {is }}$ & 18 & 4 \\
\hline $\mathrm{U}^{\mathrm{s}}$ & 53 & 23 \\
\hline $\mathrm{U}^{\mathrm{s}} / \mathrm{E}$ & 1 & \\
\hline Total & 228 & 84 \\
\hline
\end{tabular}

Inshore sites (intertidal and shallow subtidal and hard substrate habitats) typically have between 1 and 20 species present, with a few sites having much higher numbers. The offshore sites appear to have higher numbers, but we stress that only three offshore sites have been sampled for polychaetes. At all sites only limited collecting of particular habitats was undertaken and it is premature to discuss patterns of species richness within all the polychaetes. Only ten of the sampled sites have more than 20 species recorded, which is undoubtedly a gross underestimate of the diversity of polychaetes.

For a description of richness and distribution patterns, we suggest it is more informative to look at individual polychaete families, for example the terebellids, but again sampling was limited to the inshore regions (Hutchings and Glasby 1990). Of all the polychaete families for which we have morphospecies data, the Polynoidae currently yield the most reliable information on species richness and distribution patterns. This is because the collecting effort for this family has been greater with more sites sampled than for any other family, as Hanley collected at both inshore (1991, 1994) and offshore $(1987,1992)$ sites, concentrating almost exclusively on polynoids, and all material was identified. The limited conclusions, which that can be drawn from the data highlight the need for additional sampling, increasing the number of locations and habitats as individual polychaete families or species tend to have specific habitat requirements.

Species richness patterns across locations for the most part reflect the variable collection effort and cannot be interpreted as an accurate measure of species richness at any one location, especially when it is the result of a single collecting event. However, the presentation of the data in this way allows an assessment of which locations in the Kimberley have been surveyed for polychaetes, and provide an indication of the available data. Current integrative studies, incorporating genetic data with the morphological information, are demonstrating that some of the species previously considered widespread are in fact a complex of sibling species, increasing the diversity of known polychaete fauna in Australia and the Kimberley (see for example Capa et al. 2010).

The dominance of widespread species and conversely the lack of narrow range endemics in the Kimberley region reflects, in part, the collection and identification biases discussed above. Additional sampling will be required to confirm whether taxa recorded from regions contiguous with the Kimberley (i.e. southern Western Australia and Northern Territory) are also present in the Kimberley. Examples to date include the sabellariid 


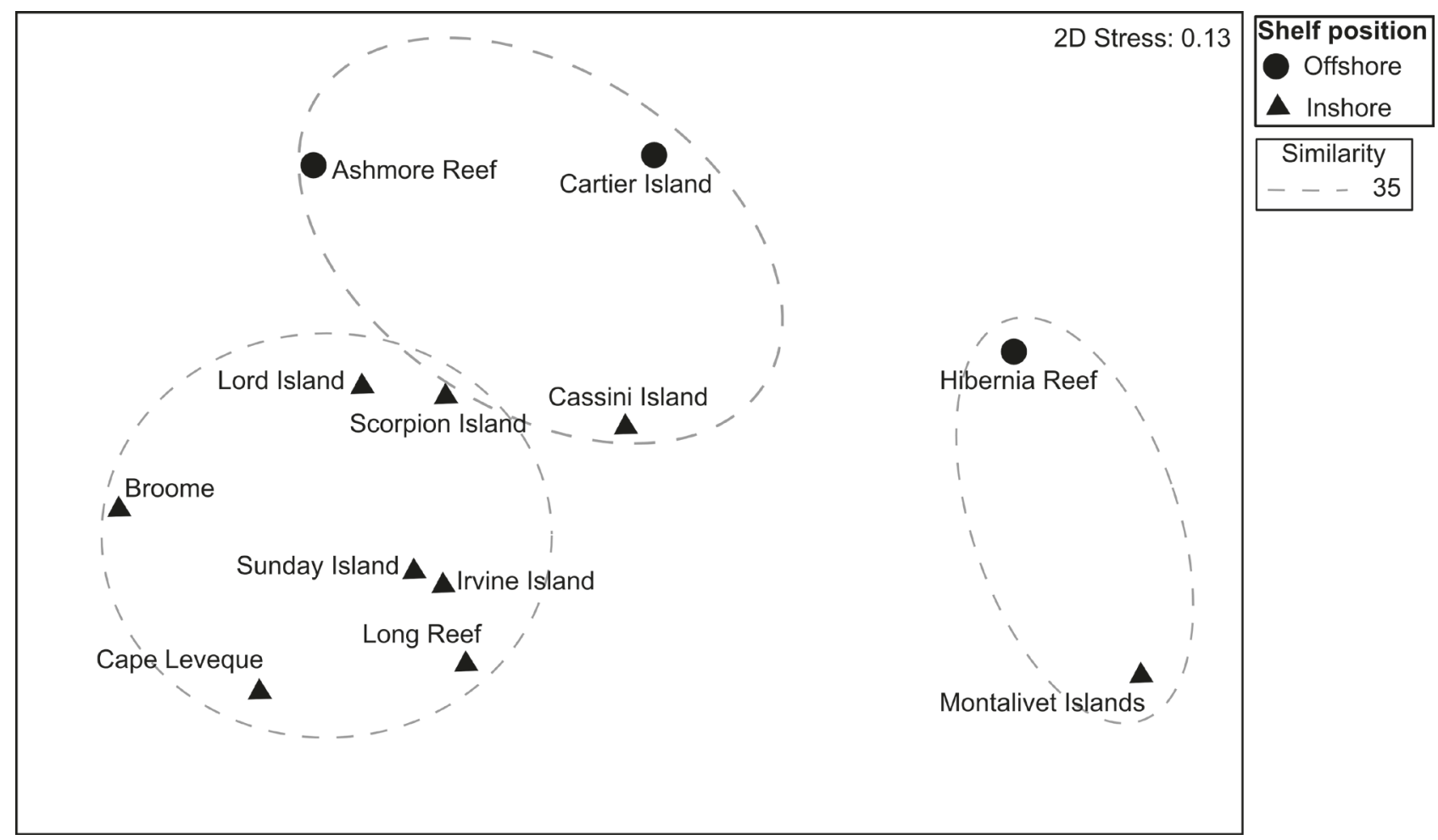

FIGURE 4 A MDS plot of the distribution of polynoids within the region.

Idanthyrsus willora (Hutchings et al. 2012), and sabellids belonging to the genera Amphicorina, Euchone and Pseudobranchiomma amongst others (Capa personal observation). Considering just the 24 terebellids identified to species, 15 are widespread Australian species, seven are restricted to Northern Australia and two are Indo-Australian. Of the 26 Nereididae species with distributional data, five are widespread Australian species, none appear to be restricted to northern Australia and 21 are widespread in the Indo-Pacific. A few nereidid species, Neanthes pachychaeta (Fauvel), Perinereis suluana (Horst) and Perinereis nuntia Savigny in Lamarck, appear to be common in the Kimberley and Indo-Australian region, but are rarely, if ever, encountered in northern Australia (Glasby personal observation).

The discussion above partly reflects the specialist interests of Russell Hanley, former curator of polychaetes at MAGNT who was particularly interested in commensal species, rather than the abundance of this family across the Kimberley region [in coral reef areas polynoids are infrequently collected (Hutchings personal observation)]. In contrast, Hutchings (1989) made extensive collections of all polychaetes, especially those associated with dead coral substrates, and targeted intertidal collecting was also done when feasible given tidal and safety issues, and subtidal soft sediments were not collected. Also, facilities for sorting in the field meant that small individuals were often overlooked. However, it should be noted that no comprehensive sampling of all habitats present in the Project Area has been undertaken to date, and this attempt to synthesise the existing data is to facilitate more comprehensive surveys of the area, which are expected, given the recognised limitations in previous sampling, to reveal a very diverse and abundant polychaete fauna.

\section{REGIONAL BIOGEOGRAPHIC COMPARISON}

At this stage it is premature to discuss the regional biogeography for the polychaetes as sampling across locations has been too variable.

Some widespread polychaetes are being shown to represent suites of cryptic species (Carlton 2009; Capa et al. 2013). For example, some current work on nereidids has shown that using both morphological and molecular data to redefine species boundaries considerably reduces the distributional ranges (Glasby et al. 2013). We suspect many of the species listed in Table 3 will be found to represent suites of species, in which case diversity estimates for the region will increase. In addition, some of the names of so-called widespread species in Table 3 will almost certainly change as revisions of these species occurs and it is likely some will be found to represent undescribed species. 


\section{FUTURE DIRECTIONS}

As revisions of individual families are undertaken the specimens in historical collections need to be re-examined and their identifications confirmed. Additional habitats need to be sampled, especially soft sediments and those from deeper water, together with environmental information such as sediment characteristics.

While polychaete collections were historically preserved in formalin, contemporary collection practice now routinely preserves material in ethanol to enable subsequent genetic studies, which are changing our taxonomic concepts - see for example Capa et al. (2010, 2013) and Wei et al. (2013). Such studies are expected to continue and the contemporary surveys underway (2009-2014) in the Project Area are undertaking such practices.

A current focus of some conservation research has been utilisation of museum data in large scale biogeographic analyses. To date the Kimberley species data have been available for use in only a very general manner, with most information on assemblages in different areas, or bioregional comparisons being derived from some well known taxa such as fishes. Polychaetes could be a useful taxon to include, but as already identified from our data, the sampling and taxonomic biases limit their value. However, it would be possible to focus on certain families, which have been both elucidated and are also well surveyed in other areas such as terebellids and nereidids. Currently C. Glasby and P. Hutchings are collaborating on such a project to utilise these families in identifying biogeographic regions and comparing them with those already identified using sediment and demersal fish data.

Finally, this historical review of the current status of polychaete knowledge in the Kimberley region can be used to identify where additional survey work is necessary to obtain a comprehensive picture of polychaete distributions in the region.

\section{ACKNOWLEDGEMENTS}

We thank our taxonomic colleagues whose substantial collections and identifications of the Kimberley polychaete fauna formed the basis of this dataset. The unpublished data of Russell Hanley on the polynoids that are housed in MAGNT have been particularly helpful. We also thank the Collection Managers in each of the museums for supplying the databases. We express our thanks to Stacey Osborne and Albert Miles for databasing the unregistered Kimberley material in WAM collections and for checking taxonomic and spatial information in this dataset and to Stacy Osborne for assistance in formatting tables for this paper. Also thanks to the reviewers who provided helpful comments.

\section{REFERENCES}

ABRS (2014). Australian Faunal Directory. Australian Biological Resources Study, Canberra. http://www. environment.gov.au/biodiversity/abrs/onlineresources/fauna/afd/index.html.

Appeltans, W., Bouchet, P., Boxshall, G.A.M, Stöhr, S., Walter, T.C. and Costello, M.J. (eds) (2010). World Register of Marine Species. Online at http://www. marinespecies.org.

Augener, H. (1914). Polychaeta II, Sedentaria. Fauna Südwest-Australiens 5: 1-170.

Augener, H. (1922). Results of Dr. E. Mjöberg's Swedish Scientific Expeditions to Australia 1910-13. Polychaeten. Kunglia Svenska vetenskapsakadamien Handlingar 63: 1-49.

Beesley, P.L., Ross, G.J.B. and Glasby, C.J. (eds). (2000). Polychaetes \& Allies: The Southern Synthesis. Fauna of Australia. Volume 4A Polychaeta, Myzostomida, Pogonophora, Echiura, Sipuncula. CSIRO Publishing: Melbourne.

Capa, M., Bybee, D.R. and Bybee, S.M. (2010). Establishing species and species boundaries in Sabellastarte Krøyer, 1856 (Annelida: Sabellidae): an integrative approach. Organisms, Diversity and Evolution 10: 351-371.

Capa, M., Pons, J. and Hutchings, P. (2013). Cryptic diversity, intraspecific phenetic plasticity and recent geographic translocations in Branchiomma (Sabellidae, Annelida). Zoologica Scripta 42: 637-655.

Carlton, J.T. (2009). Deep Invasion Ecology and the Assembly of Communities in Historical Time. (pp. 13-56). In: Rilov, G. and Crooks, J.A. (eds), Biological invasions in marine ecosystems, Volume 204. Springer: Berlin.

Department of Environment and Conservation (2009). Protecting the Kimberley. A synthesis of scientific knowledge to support conservation management in the Kimberley region of Western Australia. Unpublished Report. Department of Environment and Conservation: Perth, Western Australia.

Fauchald, K. and Rouse, G. 1997. Polychaete systematics: past and present. Zoologica Scripta 26: 71-138.

Gaston, K.J. and Mound, L.A. (1993). Taxonomy, hypothesis testing and the biodiversity crisis. Proceedings: Biological Sciences 251: 139-142.

Glasby, C.J., Wei, V. and Gibb, K. (2013) Cryptic species of Nereididae (Annelida: Polychaeta) on Australian coral reefs. Invertebrate Systematics 27: 245-264.

Hanley, J.R. (1992). Part VII. Polychaete Worms. (pp. 57-61). In: Survey of the Kimberley Islands and Reefs, Western Australia. Unpublished Report. Western Australian Museum: Perth.

Hanley, J.R. (1995). Part 10. Polychaeta. (pp. 127-136). In: Marine Biological Survey of the Southern Kimberley, Western Australia. Unpublished Report. Western Australian Museum: Perth.

Hartmann-Schröder, G. (1979). Teil 2. Die Polychaeten der tropischen Nordwestküste Australiens (zwischen Derby im Norden und Port Hedland im Süden). Zur Kenntnis des Eulittorals der australischen Küsten unter besonderer Berücksichtigung der Polychaeten 
und Ostracoden (G. Hartmann-Schröder and G. Hartmann). Mitteilungen aus dem Hamburgischen Zoologischen Museum und Institut 76: 75-218.

Hutchings, P.A. (1989). Report of Polychaete Worms Collected. (pp. 12-13). In: Survey of the Invertebrate Fauna of the Kimberley Islands, Western Australia. Unpublished Report. Western Australian Museum: Perth.

Hutchings, P.A. Capa, M. and Peart, R. (2012). Revision of the Australian Sabellariidae (Polychaeta) and description of five new species. Zootaxa 3306: 1-60.

Hutchings, P.A. and Glasby, C.J. (1990). Additional new species of the family Terebellidae (Polychaeta) from Western Australia, with a key to all described species from the region. (pp. 251-289). In: Wells, F.E., Walker, D.I., Kirkman, H. and Lethbridge, R. (eds). The Marine Flora and Fauna of Albany, Western Australia Volume 1. Western Australian Museum, Perth.

Hutchings, P.A. and Reid, A. (1990). The Nereididae (Polychaeta) from Australia - Gymnonereidinae sensu Fitzhugh, 1987: Australonereis, Ceratocephale, Dendronereides, Gymnonereis, Nicon, Olganereis and Websterinereis. Records of the Australian Museum 42: 69-100.

Hutchings, P.A. and Reid, A. (1991). The Nereididae (Polychaeta) from Australia - Leonnates, Platynereis and Solomononereis. Records of the Australian Museum 43: 47-62.

Hutchins, J.B. (1999). Biogeography of the nearshore marine fish fauna of the Kimberley, Western Australia. Proceedings of the 5th Indo-Pacific Fish Conference, Nouméa. Society of French Ichthyologists.

Johansson, K.E. (1918). Results of Dr. E. Mjöberg's Swedish Scientific Expeditions to Australia 1910-1913. Part XX. Serplulimorphe Anneliden. Kunglia Svenska Vetenskapsakademiens handlingar 58: 1-14.

Marsh, L.M. and Marshall, J.I. (1983). Some aspects of the zoogeography of northwestern Australian echinoderms (other than holothurians). Bulletin of Marine Science 33: 671-687.

Murray, A., Hutchings, P. and Pillai, T.G. (2010). Note on Hydroides malleolaspinus from the Kimberleys of
Western Australia (Polychaeta: Serpulidae). Records of the Australian Museum 62: 393.

Pillai, T.G. (2009). Descriptions of new serpulid polychaetes from the Kimberleys of Australia and discussion of Australian and Indo-West Pacific species of Spirobranchus and superficially similar taxa. Records of the Australian Museum 61: 93-199.

Pyke, G.H. and Ehrlich, P.R. (2010). Biological collections and ecological/environmental research: a review, some observations and a look to the future. Biological Reviews 85: 247-266.

Rouse, G.W. and Pleijel, F. (2001). Polychaetes. Oxford University Press, Oxford.

Russell, B.C (2005). The Ashmore Region: history and development. The Beagle, Records of the Museums and Art Galleries of the Northern Territory, Supplement 1: 1-8.

Sampey, A., Bryce, C.W., Osborne, S. and Miles, A. (2014). Kimberley marine biota. Historical data: introduction and methods. Records of the Western Australian Museum Supplement 84: 19-43.

Sampey, A. and Marsh, L.M. (2015). Kimberley marine biota. Historical data: echinoderms. Records of the Western Australian Museum Supplement 84.

Veron, J.E.N. and Marsh, L.M. (1988). Hermatypic corals of Western Australia: records and annotated species list. Records of the Western Australian Museum Supplement 29: 1-136.

Wei V., Watson, C. and Gibbs, K.S. (2013). Phylogenetic and geographic variation of northern Australian sympatric lineages of Treptopale homalos and $T$. paromolos (Annelida: Phyllodocida: Chrysopetalidae) using mitrochondrial and nuclear sequences. Marine Biology Research 9: 692-702.

Wilson, B. (2014). Kimberley marine biota. History and environment. Records of the Western Australian Museum Supplement 84: 1-18.

Wood, M. and Mills, D. (2008). A turning of the tide: science for decisions in the Kimberley-Browse marine region. Western Australian Marine Science Institute: Perth.

MANUSCRIPT RECEIVED 23 DECEMBER 2013; ACCEPTED 12 SEPTEMBER 2014. 